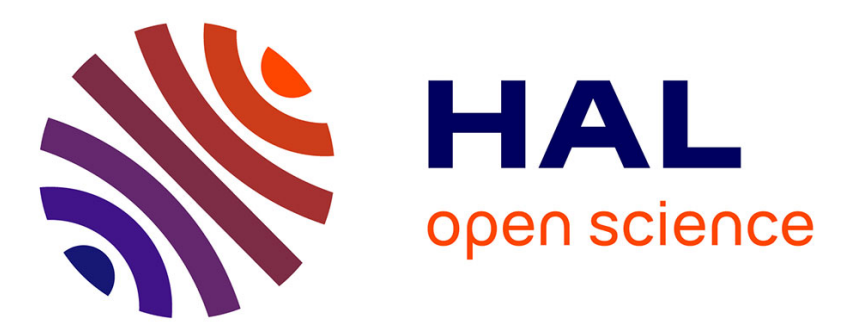

\title{
Elaboration of low-band-gap $\pi$-conjugated systems based on thieno[3,4-b]pyrazines
}

Nathalie Cheminet, Sandra Nogueira, Oumayma Benaqqa, Zakaria El Malki,

Mohamed Bourass, Simon Cassegrain, Mohammed Hamidi, Mohammed

Bouachrine, Jean-Marc Sotiropoulos, Karinne Miqueu, et al.

\section{To cite this version:}

Nathalie Cheminet, Sandra Nogueira, Oumayma Benaqqa, Zakaria El Malki, Mohamed Bourass, et al.. Elaboration of low-band-gap $\pi$-conjugated systems based on thieno[3,4-b]pyrazines. Pure and Applied Chemistry, 2020, pp.353. 10.1515/pac-2018-1009 . hal-02270781

\section{HAL Id: hal-02270781 \\ https://hal.science/hal-02270781}

Submitted on 11 Nov 2020

HAL is a multi-disciplinary open access archive for the deposit and dissemination of scientific research documents, whether they are published or not. The documents may come from teaching and research institutions in France or abroad, or from public or private research centers.
L'archive ouverte pluridisciplinaire HAL, est destinée au dépôt et à la diffusion de documents scientifiques de niveau recherche, publiés ou non, émanant des établissements d'enseignement et de recherche français ou étrangers, des laboratoires publics ou privés. 


\title{
Elaboration of low-band-gap $\pi$-conjugated systems based on thieno[3,4-b]pyrazines
}

Nathalie Cheminet, ${ }^{a}$ Sandra L. Nogueira, ${ }^{a}$ Oumayma Benaqqa, ${ }^{c}$ Zakaria El Malki, ${ }^{c}$ Mohamed Bourass, ${ }^{d}$ Simon Cassegrain, ${ }^{a}$ Mohammed Hamidi, ${ }^{c}$ Mohammed Bouachrine, ${ }^{d}$ Jean Marc Sotiropoulos, ${ }^{\mathrm{e}}$ Karinne Miqueu, ${ }^{\mathrm{e}}$ Thibaut Jarrosson ${ }^{\star, b}$, Claude Niebel, ${ }^{a}$ Jean-Pierre Lere-Porte ${ }^{\mathrm{a}}$ and Francoise Serein-Spirau ${ }^{*, b}$

\footnotetext{
a Nathalie Cheminet, Sandra L. Nogueira, Simon Cassegrain, Claude Niebel and Jean-Pierre Lère-Porte: Institut CharlesGerhardt de Montpellier, UMR CNRS 5253, Architectures Moleculaires et Materiaux Nanostructures, Ecole Nationale Superieure de Chimie de Montpellier, 8 rue de l'Ecole Normale, 34296 Montpellier, Cedex 5, France

$\mathrm{b}$ *Corresponding authors: Thibaut Jarrosson and Françoise Serein-Spirau, Institut Charles-Gerhardt de Montpellier, UMR CNRS5253, Architectures Moleculaires et Materiaux Nanostructures, Ecole Nationale Superieure de Chimie de Montpellier, 8 rue de l'Ecole Normale, 34296 Montpellier, Cedex 5, France, e-mail: Thibaut.Jarrosson@enscm.fr (T. Jarrosson); francoise.spirau@enscm.fr (F. Serein-Spirau). https://orcid.org/0000-0002-2673-4198 (T. Jarrosson)

${ }^{\mathrm{C}}$ Oumayma Benaqqa, Zakaria El Malki and Mohammed Hamidi: Faculte des sciences et techniques, BP 8509, Boutalamine, Errachidia, Morocco

${ }^{d}$ Mohamed Bourass and Mohammed Bouachrine: ESTM, (LASMAR), University Moulay Ismail, Meknes, Morocco

e Jean Marc Sotiropoulos and Karinne Miqueu: CNRS/Universite de Pau et des Pays de l'Adour, IPREM-UMR 5254, Helioparc, 2 avenue P. Angot 64053 Pau cedex 09, France
}

\begin{abstract}
In order to understand the electronic contribution of the thienopyrazine building block on the electronic properties of $\pi$-conjugated systems, small molecules containing thiophene and thienopyrazine moieties are synthesized and jointly studied by theoretical (DFT) and experimental methods (UV-Vis, UPS).Taking advantages of these preliminar attractive results, four low band gap extended structures have been elaborated on the base of DonorAcceptor-Donor sequences (DAD); these elongated $\pi$-conjugated molecules exhibit noticeable electronic and absorption properties spreading from the near UV to NIR regions.
\end{abstract}

Keywords: ח-conjugated systems; low band-gap; organic electronics; POC-17.

\section{Introduction}

Since the 90s, $\pi$-conjugated materials have attracted a continuous growth of interest due to their large properties scope that can be useful for a wide range of applications and particularly in organic electronics [1-3].Their optical and electronic properties are used in sensor devices [4, 5], in organic electroluminescent diodes[6,7], in thin film organic field effect transistors [8-13], in bulk heterojunction organic photovoltaic cells and more recently for near infrared photodetectors [3,14-17]. In order to reach better transport properties and to favour the production of technologically useful materials, it appears essential to study the relationships between the chemical structures and electronic and optical properties for this goal. The band gap control remains a decisive parameter.

Conversely, among the large diversity of chemical structures, thieno[3,4-b]pyrazines are well known to be suitable sub-structures to stabilize quinoid resonance moieties. 
Therefore, they appear to be good candidates to efficiently reduce the band gap [18, 19]. Consequently, thieno[3,4-b]pyrazine building blocks are appropriate to enhance planarity of sequences leading to fully conjugated segments. Indeed, N-containing heterocyclic aromatics like thieno[3,4-b]pyrazines are described to behave as relevant electron acceptors; this species are easily tunable and dependant, on the one hand, on the two substituents in the 2 and 5 positions on the thiophene unit and, on the other hand, on the two groups borne on the adjacent carbons to the nitrogen atoms.

This study exhibits the role of the heterocyclic six membered pyrazine condensed on the thiophene ring,relative to the LUMO energy level of small model molecules. A similar process is carried out on slightly longer $\pi$-conjugated systems that are finally included in an alternated donor $(D)$-acceptor $(A)$ sequence in order to build a D-A-D extended conjugated structures.

\section{Results and discussion}

\section{Elaboration of parent thienopyrazines $3 a-f$}

\section{Synthesis}

Compounds 3 are prepared by condensing 3,4-diaminothiophene with a 1,2-diketone [20]. In this synthesis, 3,4-diaminothiophene was generated in situ from the ammonium salt 1 using triethylamine as a base (Fig. 1).

To vary the $Z$ substituents, two condensation methods were explored using a wide range of 1,2-diketones. In a first methodology, the 1,2-diketones are condensed in refluxing absolute ethanol (Method 1). In those conditions, an optimal yield is obtained under 3 days refluxing. Alternatively, microwave activation [21] (at $150{ }^{\circ} \mathrm{C}$ in absolute ethanol) decreases the reaction time to only $10 \mathrm{~min}$ (Method 2). Only four compounds $\mathbf{3} \mathbf{a}-\mathbf{d}$ are isolated by common extraction methods and purified on silica gel by flash chromatography. Overall, reaction yields vary from low to fair (22-52\%), probably due to the low stability of the deprotonated "diamino" starting material 1. 3e cannot be isolated, because of its poor stability; 3f, bearing an extended flat $\pi$ system, exhibit a little solubility and is not obtained.

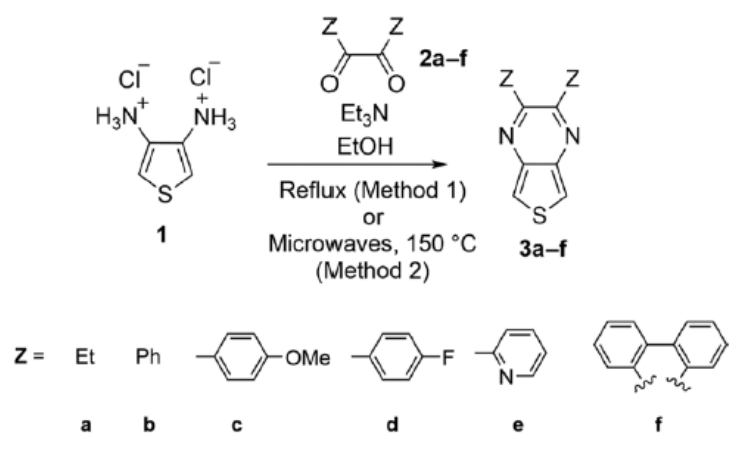

Fig. 1: Synthesis of thienopyrazine series $\mathbf{3 a - f .}$ 


\section{Electronic and optical properties of compounds $3 a-d$}

In a first step, interest was dedicated to better appreciate, in terms of frontier orbitals levels, the role of the pyrazine condensed ring itself on the thiophene moiety to build the thienopyrazine structure: density functional theory (DFT) computational studies were undertaken to evaluate molecular orbitals levels and electronic band-gaps of the systems. Every compound geometries were first optimized with DFT B3LYP functional and 6-31G** basis set. At the minimum energy level, all the thienopyrazines, here reported, prove a planar structure and confirm an extended conjugation as previously reported [10,11, 22]. Precisely, calculated frontier molecular orbitals levels of the thiophene ring exhibit, in these conditions, $\mathrm{HOMO}$ and LUMO ones at -6.35 and $-0.23 \mathrm{eV}$, respectively (Fig. 2), giving an electronic gap Eg of $6.12 \mathrm{eV}$. Referring to thienopyrazines 3a-d HOMO and LUMO levels and band gaps calculations which are reported in Table 3, the introduction of the pyrazine ring fused to the thiophene moiety dramatically decreases their LUMO level and consequently contributes to a significant reduction of the gap Eg inducing an extended conjugation. Moreover, the $Z$ substituents of the pyrazine sub-structure impact the LUMO levels values but no correlation can be easily established with the LUMO level and the band gap value in relation with their significant well-known electronic effects: indeed, geometric parameters due to steric hindrances origin a calculated dihedral bond angle of about $40^{\circ}$ between the thienopyrazine units and the $Z$ substituent, confirming the $Z$ substituents role on the band gap tuning.

To validate the electronic properties established by the calculations results, ultraviolet photoelectrons spectroscopy experiments (UPS), in the gas phase, have been carried out on 3a-d compounds. Photoelectrons spectrum of compound $\mathbf{3 b}$ given as an example in Fig. $3 \mathbf{a}$ gives the ionization potentials exhibiting three bands at $9 \mathrm{eV}$, about $10 \mathrm{eV}$ and at $11 \mathrm{eV}$ that can be respectively correlated to the HOMO, HOMO-1 and HOMO-2 levels. These experimental data are in accordance with DFT computational studies, enabling to clearly attribute the band at $9 \mathrm{eV}$ to the HOMO orbitals.

Moreover, experimental electronic and optical properties of compounds $\mathbf{3 a - d}$ are recorded and evidence to value the substituents $Z$ effect on the absorption properties useful to estimate the optical band gap (Table 1). Absorption maxima are in the range of 315-348 nm and emission properties are included in the 450-465 $\mathrm{nm}$ region. These experimental data are compared to computational time dependent density functional theory (TD-DFT) analysis, dedicated to predict the absorption spectrum. Even if optical band gap does not stricly correspond to the value of the molecular band gap Eg, the two gap values are informative and can be given and compared. Optical gaps deduced from absorption maxima data are in good agreement with the experimental data (Table 1). Comparing the absorption maxima of the four compounds $\mathbf{3 a - d}$, the lowest one is observed for $\mathbf{3 a}$ when the $Z$ substituents are ethyl groups: ethyl group cannot participate or increase any conjugation. Otherwise, when the substituents 
are phenylene groups, they can participate to the thienopyrazine conjugation and play a more significant effect. Comparing $\mathbf{3 a}$ and $\mathbf{3 b}$, a $\mathbf{3 0} \mathrm{nm}$ bathochromic effect is recorded and this tendency is confirmed when phenylene rings are para substituted by a methoxy or a fluorine group. As expected, the electronic nature of the methoxy (donnor effect) or the fluorine (acceptor effect) clearly influence the electronic properties of compounds $\mathbf{3 c}$ and $\mathbf{3 d}$. The phenylene substituent electronic role manages the HOMO and LUMO levels and therefore the electronic gap of the compounds but, surprisingly, does not impact the emission properties.

Table 1: Electronic properties of compounds $3 \mathbf{a}-\mathbf{d}$.

\begin{tabular}{|c|c|c|c|c|c|c|c|}
\hline \multirow[t]{2}{*}{$\mathrm{z}$} & \multirow[t]{2}{*}{ Compound 3} & \multirow{2}{*}{$\begin{array}{r}\text { Yield } \\
\text { a: method } 1 \\
\text { b: method } 2\end{array}$} & \multicolumn{2}{|c|}{$\begin{array}{r}\text { Experimental values } \\
\lambda_{\max }(\mathrm{nm}) \\
\end{array}$} & \multicolumn{3}{|c|}{ Calculated values (DFT and TDDFT values } \\
\hline & & & Absorption & Emission & $\begin{array}{r}\text { Absorption } \\
\lambda_{\max }(\mathrm{nm}) \\
\end{array}$ & $\begin{array}{r}\text { Optical-gap } \\
(\mathrm{eV})\end{array}$ & $\begin{array}{r}E_{\text {sLE (Lимономоо) }} \\
(\mathrm{eV}) \\
\end{array}$ \\
\hline Et & a & $51 \%^{\mathrm{a}}$ & 315 & 450 & 281 & 4.40 & 4.05 \\
\hline $\mathrm{Ph}$ & b & $\begin{array}{l}26 \%^{\mathrm{a}} \\
20 \%^{\mathrm{b}}\end{array}$ & 347 & 465 & 357 & 3.46 & 3.75 \\
\hline & c & $22 \%^{a}$ & 378 & 460 & 398 & 3.11 & 3.72 \\
\hline-1 & d & $\begin{array}{l}43 \%^{\mathrm{a}} \\
30 \%^{\mathrm{b}}\end{array}$ & 348 & 460 & 366 & 3.38 & 3.13 \\
\hline
\end{tabular}

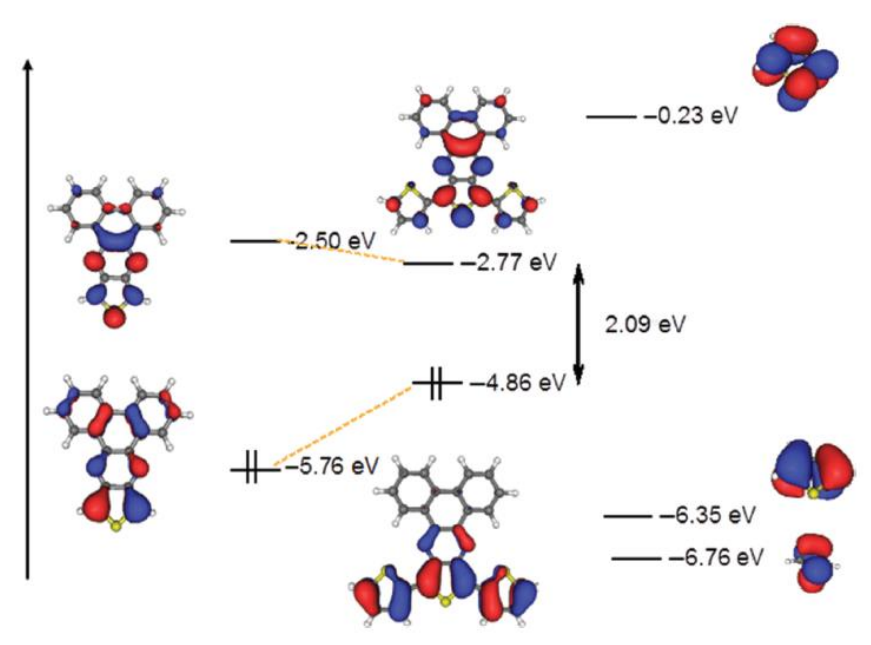

Fig. 2: HOMO and LUMO molecular orbitals correlation diagram of $\mathbf{7 f}$ from molecular orbital fragments. 

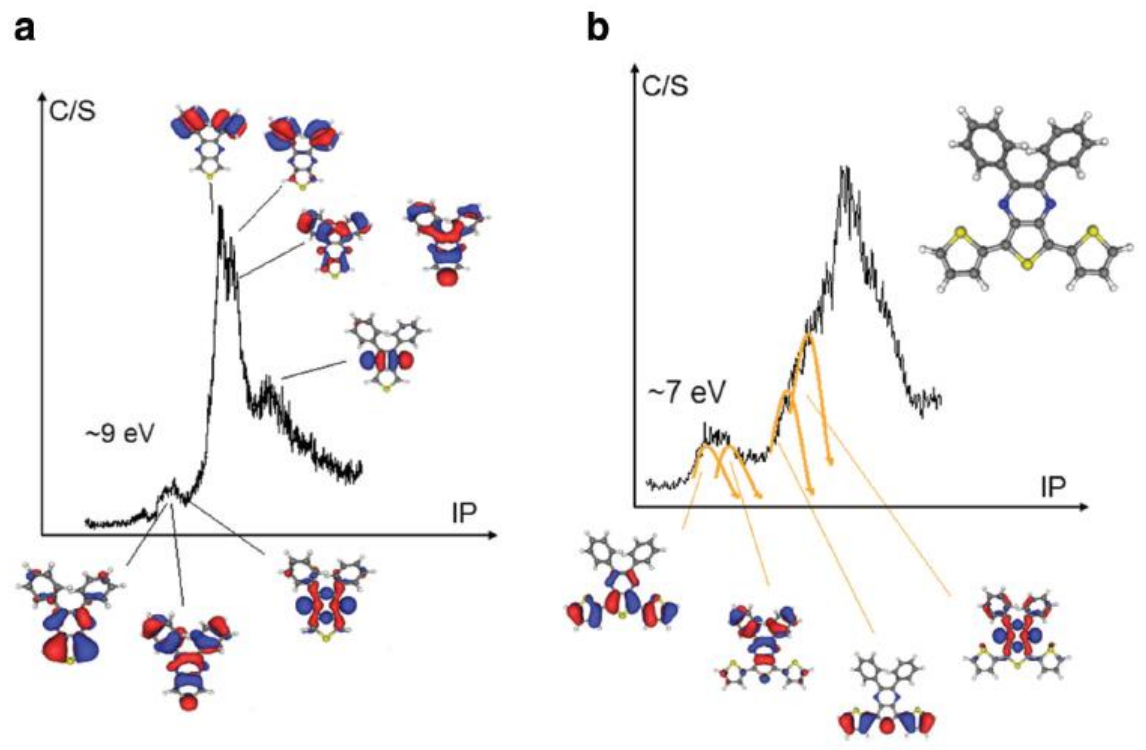

Fig. 3: Gas phase ultraviolet photoelectron spectrum (UPS) of $\mathbf{3 b}(a)$ and $\mathbf{7 b}$ (b).

\section{Elaboration of thiophene disubstituted thienopyrazine compounds 7}

A second class, made by adding two thiophene units on the thienopyrazine structure has been elaborated in order to study if the resulting extended structure follows similar electronic behaviours, concerning the determining parameters on their conjugation properties (Fig. 4).
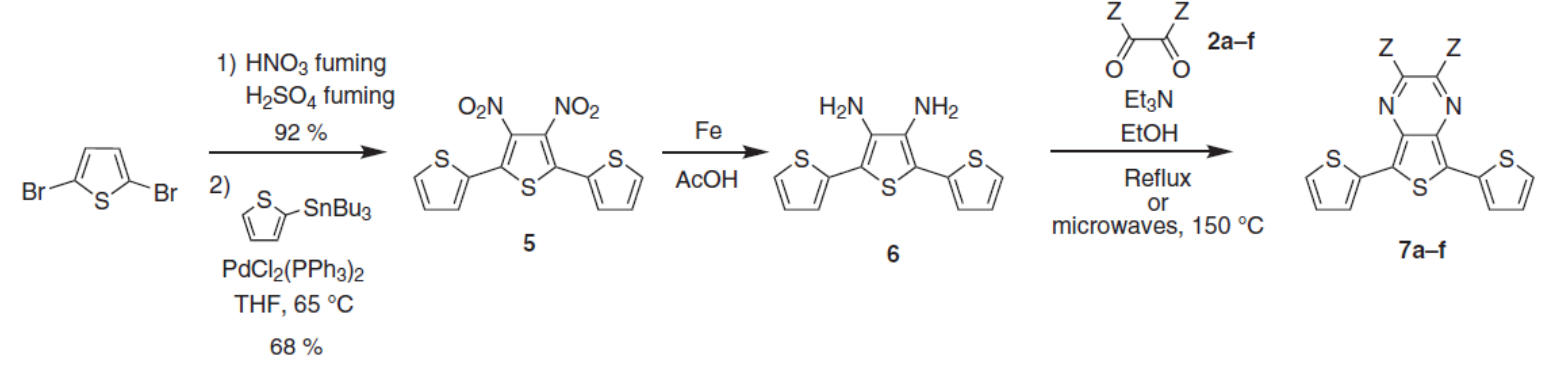

Fig. 4: Synthesis of compounds 7a-f.

\section{Synthesis}

The $\pi$-elongated thienopyrazines $7 a-f$ are prepared following literature procedures [23, 24]. The synthetic route starts with the quasi quantitative dinitration of 2,5-dibromothiophene under strong acidic condi tions. Then a double Stille cross-coupling reaction is engaged with 
2-tributylstannylthiophene and $4 \%$ of $\mathrm{PdCl}_{2}\left(\mathrm{PPh}_{3}\right)_{2}$ as the pre-catalyst to obtain 5 in good yield (68\%). The reduction of the two nitro groups with iron in glacial acetic acid at $60^{\circ} \mathrm{C}$ leads after $16 \mathrm{~h}$ to the quantitative formation (95\%) of the diamino corresponding compound 6 which was quickly engaged in the next step because it is air sensitive. As previously described for compounds $\mathbf{3 a}-\mathbf{d}$, the condensation of $\mathbf{6}$ with the appropriate 1,2-diketones $\mathbf{2 a - f}$ was realised under regular heating method or under microwave irradiation. Yields of $7 \mathbf{a}-\mathbf{f}$ elaborations are reported in Table 2 and are better for longer compounds 7a-f (25-65\%) than for 3a-d products: this can be explained by the better solubility of the longer products compared to the small systems. In this series, diketones $2 \mathbf{e}$ and $2 \mathbf{f}$ can be successfully condensed on the diamino precursor and enabled us to extend our evaluation study.

\section{Electronic and optical properties of compounds 7a-f}

The same methodology involved in the $\mathbf{3 a - d}$ electronic behaviour understanding, is implemented to study the role of the pyrazine condensed ring on the central thiophene moiety of a terthiophene entity to build the thienopyrazine structure. The same computational conditions previously described are used: calculated frontiers molecular orbitals levels of terthiophene located HOMO and LUMO ones at -6.17 and $-1.68 \mathrm{eV}$, respectively, giving an electronic gap Eg of $3.49 \mathrm{eV}$. This lower value compared to that of thiophene $(6.12 \mathrm{eV})$ is due to the $\pi$-conjugated system lengthening.

Considering thienopyrazine derivatives $7 \mathbf{a}-\mathbf{f}$, their LUMO levels and their band gaps Eg are significatively reduced and as it was concluded for compounds $\mathbf{3 a - d}$, this evolution is due to the pyrazine substructure presence in the chemical conjugated segment. UPS spectra are recorded in the gas phase for compounds 7 , showing two main bands with a poorer resolution: the comparison of the lower energy band $(7 \mathrm{eV})$ of $\mathbf{7 b}$, taken as an example, with that of $\mathbf{3 b}(9 \mathrm{eV})$ indicates a noticeable extension of conjugation between the two series of compounds. Deconvolution of the bands enables the identification of some molecular orbitals as shown in Fig. 3b.

From molecular orbital fragments of thienopyrazine 7f, HOMO and LUMO molecular orbitals correlation diagram is presented in Fig. 2. This type of analysis has been studied by A. S. Özen with molecules containing thiophene and thienopyrazine building blocks [19]. It appears that the LUMO of compound $7 f$ comes from almost exclusively the thienopyrazine unit. On the other hand, the HOMO orbital of $\mathbf{7 f}$ is a mix between the thiophene and the thienopyrazine units. As shown in Fig. 2, the HOMO is delocalized on all the three thiophene units.

In all compounds, whereas the HOMO levels appear slightly influenced by the thienopyrazine presence in the conjugated sequence, the geometric and the electronic 
properties of the $Z$ substituents on the pyrazine moiety drastically decrease the LUMO level. For this purpose, phenylene substituents and para substituted ones are more efficient than ethyl groups; among these aromatic structures biphenyl structure leading to $7 \mathrm{f}$ reveals to be remarkably efficient to decrease the LUMO level because it freezes the thienopyrazine core in a rigid and planar morphology, consequently enhancing the conjugation of the segment (Fig. 5). Optical properties of compounds 7a-f indicate absorption maxima in the range of 504-630 $\mathrm{nm}$ and emission properties in the $620-725 \mathrm{~nm}$ region (Table 2). The experimental results are in accordance with the theoretical calculations tendencies. Conversely, when $\mathbf{3 c}$ and $\mathbf{3 d}$ optical properties are compared to $\mathbf{7} \mathbf{c}$ and $\mathbf{7 d}$ absorption properties, the latter are not influenced by the para substituent (methoxy or fluorine) on the phenylene ring. Among these results, experimental optical data confirm $\mathbf{7 f}$ interesting extended conjugation brought by the resulting planar phenanthrene substructure fused on the thienopyrazine moiety with an absorption maximum located at $630 \mathrm{~nm}$. This result confirms the importance of planarity on the expansion of the $\pi$-system [8].

Comparing the two classes of thienopyrazine derivatives, a huge bathochromic shift of around $200 \mathrm{~nm}$ is observed between the parent thienopyrazines $\mathbf{3 a - d}$ and the $\pi$-elongated thienopyrazines $\mathbf{7 a - d}$ and considering the small increase of the $\pi$-system, this red shift is relatively important and indicates how much efficient the thienopyrazine moiety is to improve conjugation of a m-conjugated segment.

Table 2: Electronic properties of compounds 7.

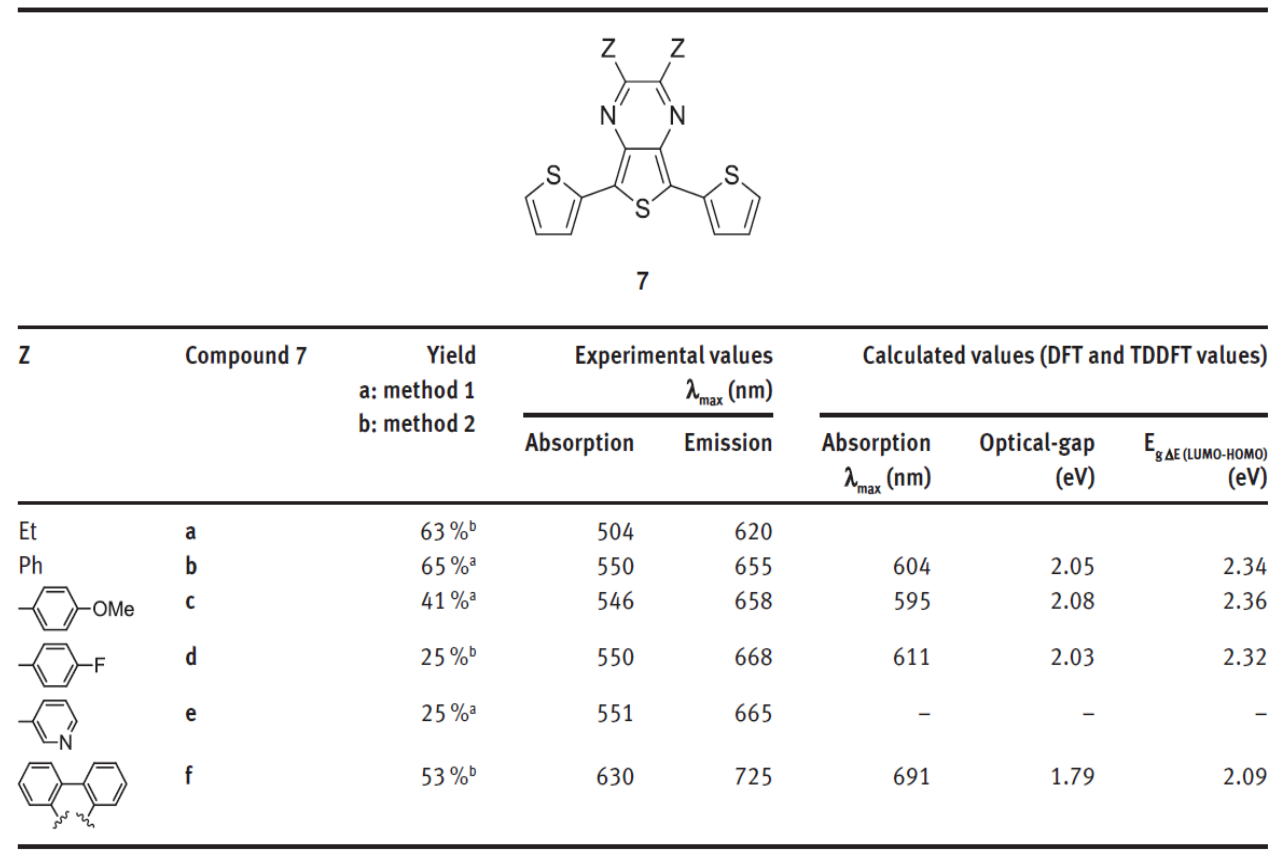


Table 3: Calculated HOMO and LUMO levels and electronic band-gap Egap (eV) of compounds 3 and 7.

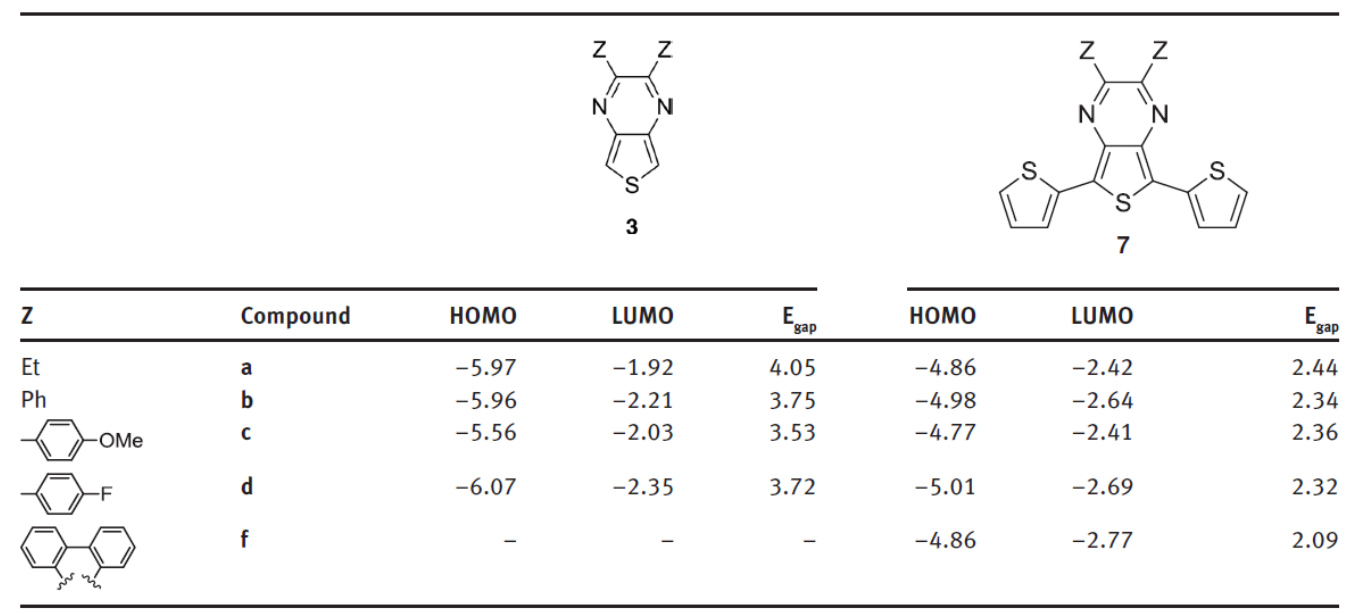
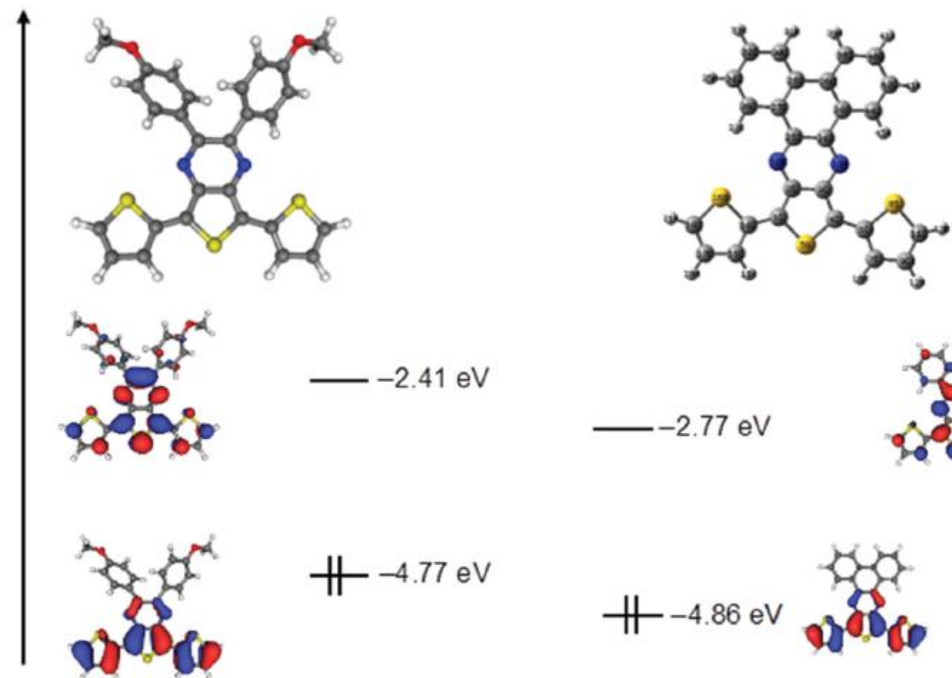

$-2.77 \mathrm{eV}$

Fig. 5: Molecular orbitals HOMO and LUMO of 7c and 7f.

\section{Elaboration of thienopyrazines based DAD sequences 12}

As demonstrated above, thienopyrazine sequences are relevant to elaborate fully conjugated systems and can operate as electron acceptors entities having a rather low LUMO level. In order to develop interesting advanced materials for electronic organics, fully conjugated materials are aspired to include requirements concerning their optical properties up to the near infra-red domain. For this purpose, the band-gap needs to be low and a strategy to decrease the gap, described by Roncali [8], is in a first step, the planarization and the rigidification of the $\pi$ system by covalent and non-covalent bonding. Secondly, this goal can 
also be reached by associating $\pi$-conjugated donors (D) and $\pi$-conjugated acceptors (A) building blocks.

Disubstituted $[3,4-b]$ thienopyrazines described above will be the electron acceptors units and will be combined to two $\pi$-conjugated electron donors as [bisthiophene 1,4-bis-(2ethylhexyloxy)phenylene] in order to build DAD sequences [25].

\section{Synthesis}

In a first strategy towards the synthesis of the DAD systems 12, a two steps process is envisaged starting with the direct dibromation on the a position of the thiophene units of $7 a-d$ (Fig. 6). By following a literature procedure [26, 27], two equivalents of $\mathrm{N}$-bromosuccinimide in chloroform are engaged, but in our hands, the dibrominated compound $\mathbf{8}$ cannot be isolated, observing the decomposition of the starting material 7. Changing the experimental conditions such as the temperature or solvents is not successful. Therefore, in order to prepare the dibrominated compounds $\mathbf{8 a - f}$, a second strategy is carried out starting from the previously described dinitro terthiophene derivative $\mathbf{5}$. In the first step, $\mathbf{5}$ was dibrominated in DMF with two equivalents of $\mathrm{N}$-bromosuccinimide leading to compound 9 in good yield (66\%). In this reaction, choosing a high polar solvent (DMF) proves to be important because of the low reactivity of the terthiophene derivative $\mathbf{8}$. The two nitro groups are then reduced using iron in acetic acid at $60{ }^{\circ} \mathrm{C}$, to obtain quantitatively (95\%) and selectively the diamino compound 10 . Condensation with the appropriate 1,2-disubstituted diketone 2 enables to obtain with the [(5(2,5-bis((2-ethylhexyl)oxy)-4-(thiophen-2-yl)phenyl)thiophen-2-yl)tributylstannane] 11 leads to the isolated desired DAD $\pi$-conjugated segments $12 \mathrm{a}-\mathbf{d}$. Unfortunately, $12 \mathrm{f}$ containing the thienopyrazine fused phenanthrene subunit cannot be isolated because of the very low solubility of the dibrominated intermediate 8f. Likewise, the low yields in this last Stille coupling reaction (from 10 to $50 \%$ ), pushed us to adopt a third strategy where the solubility is carried out upstream from the synthetic route. In this approach, 9 is engaged in a double Stille crosscoupling reaction with the monostannylated donor 11 , leading to the extended dinitro $\pi$-system 13. The two nitro groups are then quantitatively reduced (95\%) using iron in acetic acid and condensation of the diamino corresponding compound 14 with 9,10-phenanthrenedione allowed the formation of $\mathbf{1 2 f}$ ( $28 \%$ yield) which could not be isolated using the precedent synthetic strategy. On the whole, the second and the third synthetic strategies here mentioned consist in four steps (from compounds 5 to 12). The third synthetic route feasibility remains only experimented to obtain compounds $12 b$ and $12 f$. For $12 b$, the two synthetic routes are quite identical concerning the elaboration overall yield (Table 4). For $\mathbf{1 2 f}$, the only efficient preparative pathway, for solubility reasons, is the third strategy, that gives an overall yield of $5.3 \%$ over the four steps. 


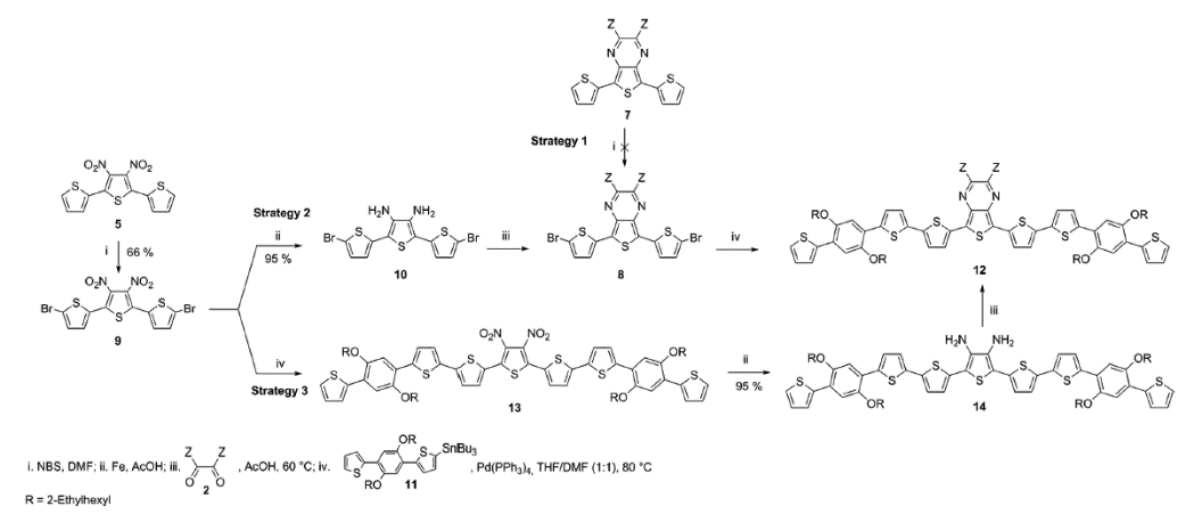

Fig. 6: Two strategies for the synthesis of thienopyrazine based DAD systems.

Table 4: Yields of compounds 12.

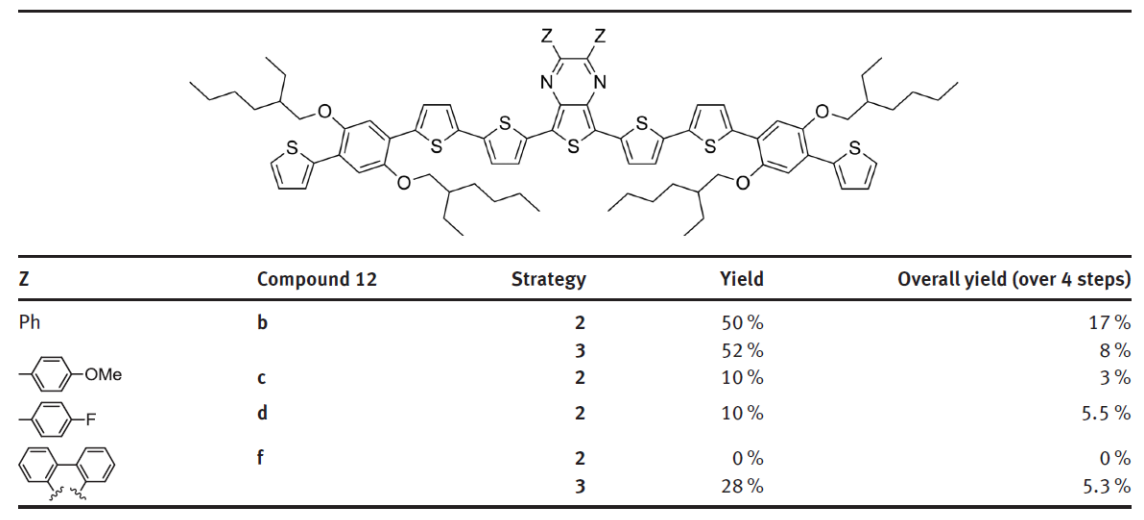

\section{Electronic and optical properties of compounds 12}

The UV-Vis maximum absorption of these thienopyrazine-based compounds highlights a significant increase due to the extended conjugation (Fig. 7a). Concerning 12f extra conjugation is reached because of the rigidification of the $\pi$-conjugated system in a flat conformation thanks to the phenanthrene substructure. The experimental UV-Vis spectrum of $\mathbf{1 2 f}$ gives an absorption maximum of $742 \mathrm{~nm}$. It reveals that $\mathbf{1 2 f}$ absorbs in the whole domain of the visible light (from $400 \mathrm{~nm}$ to $900 \mathrm{~nm}$ ), exhibiting their interest to develop organic solar cells (Table 5). The HOMO-LUMO orbital diagrams shown in Fig. 8 demonstrate that the HOMO orbital is delocalized on the five central thiophene rings, while the LUMO orbital is concentrated on the thienopyrazine subunit. As for $\mathbf{7 c}$ and $\mathbf{7 d}$, absorption properties of $\mathbf{1 2 c}$ and $\mathbf{1 2 d}$ are not influenced by the para substituent (methoxy or fluorine) on the phenylene ring. To experimentally determine HOMO and LUMO energy levels of compounds 12, cyclic voltammetry analysis is additionally performed in $0.1 \mathrm{M}$ of TBAPF6 solution in dichloromethane using a $50 \mathrm{mV} / \mathrm{s}$ scan speed. 
Experimental and calculated frontiers orbitals levels values are recorded in Table 5 and are in good correlation, indicating the relevance of the DFT method to predict and value the electronic properties of this kind of compounds. In the solid state obtained from drop casted films from $\mathrm{CHCl}_{3}$ solutions, $30-50 \mathrm{~nm}$ red-shifts are recorded for $\mathbf{1 2} \mathbf{b}-\mathbf{d}$ in the absorption spectra compared to the solution ones (Fig. 7b). Interestingly, for $\mathbf{1 2 f}$, the bathochromic shift is only $15 \mathrm{~nm}$, probably revealing, its more planar conformation in the solution state compared to the other compounds.

a

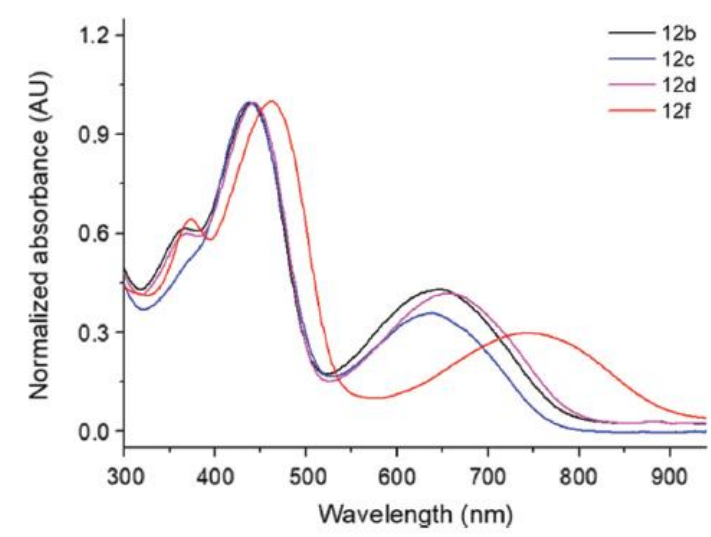

b

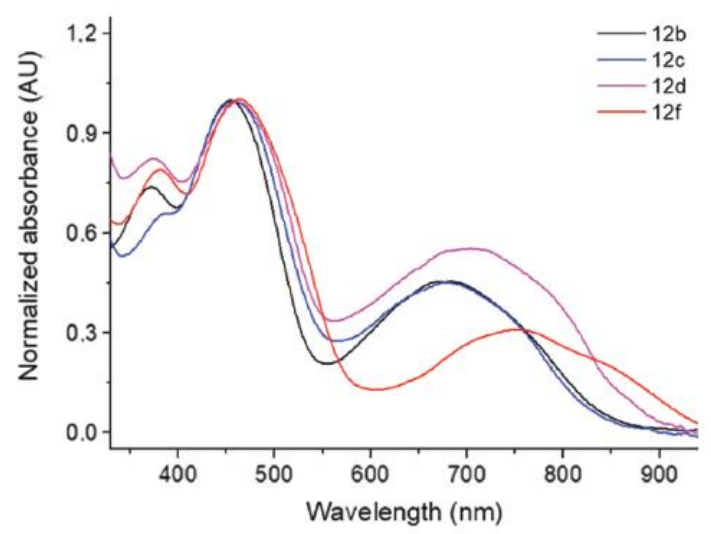

Fig. 7: (a) Absorption spectrum of 12b-d and $\mathbf{1 2} \mathbf{f}$ in $\mathrm{CHCl}_{3}$. (b) Absorption spectrum of $\mathbf{1 2 b}-$ d and $\mathbf{1 2 f}$ drop casted thin films from a $\mathrm{CHCl}_{3}$ solution.

Table 5: Optical and electronic properties of compounds 12 in solution.

\begin{tabular}{|c|c|c|c|c|c|c|c|}
\hline \multicolumn{4}{|c|}{ Compound } & \multicolumn{2}{|c|}{ Energy levels } & \multirow{2}{*}{$\begin{array}{r}\begin{array}{r}\text { Electrochemical } \\
\text { band gap }\end{array} \\
\mathrm{E}_{\mathrm{g}}(\mathrm{eV})\end{array}$} & \multirow{2}{*}{$\begin{array}{l}\text { Optical band gap } \\
\mathrm{E}_{\mathrm{g}}(\mathrm{eV})\end{array}$} \\
\hline z & 12 & & $\lambda_{\text {max }}(\mathrm{nm})$ & номо & LUMO & & \\
\hline \multirow[t]{6}{*}{$\mathrm{Ph}$} & b & Exp & 648 & -4.49 & -2.67 & 1.82 & 1.57 \\
\hline & & Calc. & 797 & -4.46 & -2.61 & 1.84 & \\
\hline & $d$ & Exp & 660 & -4.57 & -2.64 & 1.93 & 1.54 \\
\hline & & Calc. & 783 & -4.51 & -2.69 & 1.92 & \\
\hline & f & Exp & 742 & -4.54 & -2.99 & 1.55 & 1.36 \\
\hline & & Calc. & 914 & -4.37 & -2.77 & 1.60 & \\
\hline
\end{tabular}



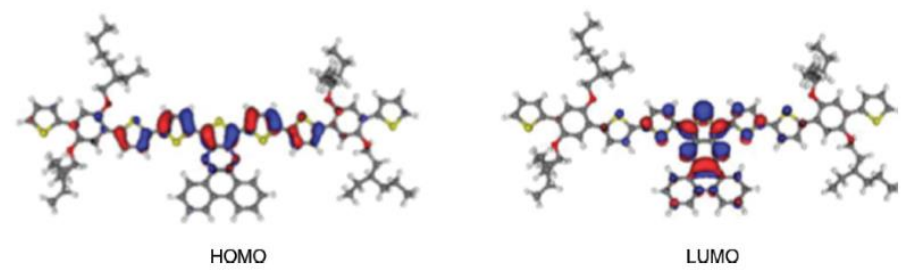

Fig. 8: HOMO and LUMO molecular orbitals representation of $\mathbf{1 2 f .}$

\section{Conclusion}

The strategy here presented to elaborate thienopyrazine based donor acceptor lowband-gap compounds is based on the understanding of the electronic contribution of the building block thienopyrazine. The first step is the synthesis and the characterization of the smallest thienopyrazine models to validate the required electronic properties and the good accordance between experimental data and theoretical calculations. In the second step, the $\pi$-conjugated system is elongated and the same methodology is implemented leading to conclude that the thienopyrazine substructure is suitable to build fully extended $\pi$-conjugated targets. After these insightful results, we take advantage of thienopyrazine based compounds to lower the LUMO level and to combine it with donor compounds having a high HOMO level in order to elaborate low band gaps systems.

In this way, four soluble extended conjugated targets are elaborated exhibiting absorption properties ranging from the entire visible spectrum to the near infrared region.

\section{Experimental section}

\section{Chemicals and instrumentation}

Unless otherwise noted, all chemicals were purchased from Aldrich, Alfa-Aesar, Fluorochem, $\mathrm{TCl}$ or Acros and used without further purification. TLC were performed using aluminium sheet covered by $\mathrm{SiO}_{2}$ Silica gel 60F254 (Merck), and column chromatography using Silica gel 60 (particle size $0.063-0.200 \mathrm{~mm}$, Merck). apparatus.

Microwaves reactions were performed in sealed tubes using a CEM Discover

1H-NMR $(400 \mathrm{MHz})$ and 13C-NMR $(101 \mathrm{MHz})$ were recorded on Bruker Avance 400. Chemical shifts are given in ppm and coupling constants $\mathrm{J}$ in $\mathrm{Hz}$. The residual signal of the solvent was taken as internal reference standard.

IR spectra were recorded using a Perkin-Elmer Spectrum 100 ATR spectrophotometer. Absorption spectra were recorded using a Hewlett-Packard 8453 spectrophotometer.

Fluorecence spectra were recorded with a Perkin Elmer LS55.

Cyclic Voltammetry was performed in a three electrodes cell filled with a $\mathrm{CH}_{3} \mathrm{CN}$ solution of $\mathrm{Bu}_{4} \mathrm{NPF}_{6}(0.1 \mathrm{M})$ using EGG 273 potentiostat. Platinum wire electrodes were used as working and counter electrodes. A silver wire was used as pseudo-reference electrode (calculated using a $1.5 \mathrm{mM}$ solution of ferrocene/ferrocinium couple).

EI-HRMS measurements were made on a Waters AutoSpec 6 and MALDI-ToF experiments on a Waters QToF Premier. 
Infrared absorption spectra were recorded on a Perkin Elmer 1000 spectrometer.

The photoelectron spectra were recorded on the homemade "Phenixl" instrument equipped with $127^{\circ}$ cylindrical analyser and monitored by a micro-computer supplemented with a digital analogic converter. The spectra were calibrated with the known auto-ionisation of helium at $4.99 \mathrm{eV}[\mathrm{He}(\mathrm{II}) / \mathrm{He}(\mathrm{I})]$ and xenon ionisations at 12.13 and $13.44 \mathrm{eV}$. All the products were vaporised thanks to the beam heat at 10-6 mbar. We maintain a stable temperature of the beam in order to vaporize enough compound and obtain intense spectra. Compounds 5 , 6, 9 and 10 were prepared following literatures protocols [23, 24].

\section{Computational details}

Calculations were performed with the Gaussian 09 suite of programs [28] using the density functional method [29]. The hybrid exchange functional B3LYP [30-32] set were used. All atoms have been described with a $6-31 \mathrm{G}(\mathrm{d}, \mathrm{p})$ basis set. Geometry optimisations were carried out without any symmetry restrictions, the minimum was verified with analytical frequency calculations. The UV/Visible absorption spectra were calculated within the Timedependent DFT formalism available in the Gaussian code using B3LYP/6-31G(d,p) level of theory.

\section{Experimental procedure and characterization data}

\section{General procedures for the preparation of thienopyrazines 3a-d}

Method 1: In a $50 \mathrm{~mL}$ two-necked round-bottom flask were added under nitrogen $3.21 \mathrm{mmol}$ (1.2 eq.) of thiophene-3,4-diammonium chloride 1 and $2.67 \mathrm{mmol}$ (1.0 eq.) of the 1,2 diketone 2 in $8.0 \mathrm{~mL}$ of absolute ethanol. Then, $0.9 \mathrm{~mL}$ of triethylamine was added dropwise and the mixture was stirred and refluxed for 3 days. After evaporation of the solvent under reduced pressure, the residue is purified by flash chromatography.

Method 2: In an adequate microwaves vessel were added under nitrogen $1.07 \mathrm{mmol}$ (1.2 eq.) of thiophene-3,4-diammonium chloride and $0.890 \mathrm{mmol}(1.0$ eq.) of the 1,2-diketone 2 in 7.0 $\mathrm{mL}$ of absolute ethanol. $0.7 \mathrm{~mL}$ of triethylamine was then added and the reaction mixture was stirred and warmed up at $150{ }^{\circ} \mathrm{C}$ for $10 \mathrm{~min}$ under microwave radiations (200 W). After evaporation of the solvent under reduced pressure, the residue is purified by flash chromatography.

\section{2,3-Diethylthieno[3,4-b]pyrazine 3a $(\mathrm{Z}=\mathrm{Et})$}

The crude product, synthesized by method 1 , is purified by flash chromatography using cyclohexane/ $\mathrm{CH}_{2} \mathrm{Cl}_{2}$ as the eluent (75/25-0/100) to obtain $3 a(260 \mathrm{mg}, 51 \%)$ as a brownish powder.

NMR 1H $\left(\mathrm{CHCl}_{3}\right), \delta(\mathrm{ppm}): 7.77$ (s, 2H, HTh), 2.88 (q, J = 7.4 Hz, 4H, CH2 H ), 1.33 (t, $J=7.4 \mathrm{~Hz}, 6 \mathrm{H}, \mathrm{CH} 3 \mathrm{H})$. NMR 13C $\left(\mathrm{CHCl}_{3}\right), \delta$ (ppm): 156.9, 141.7, 115.9, 28.6, 12.0 .

IR (cm-1): 3065, 2976, 2935, 2904, 1704, 1503, 1462, 1448, 1376, 1235, 1224, 1181, $1108,1052,1004,967,877,845$.

UV $\left(\mathrm{CHCl}_{3}\right)$ 10-4 M, $\lambda$ max: $315 \mathrm{~nm}$.

MS (EI) $\mathrm{m} / \mathrm{z}(\%): 192.1$ (100, M+), 177.1 (75), 81.9 (37), 136.0 (33). MSHR (EI): M+ Calculated 192.0716; Found 192.0718.

\section{2,3-Diphenylthieno[3,4-b]pyrazine 3b $(\mathrm{Z}=\mathrm{Ph})$}

The crude product is purified by flash chromatography using $\mathrm{CH}_{2} \mathrm{Cl}_{2} / \mathrm{EtOAc}(100 / 0-$ $75 / 25$ ) to obtain $\mathbf{3 b}$ (method 1: $300 \mathrm{mg}, 26 \%$, method 2: $60 \mathrm{mg}, 20 \%$ ) as a brownish powder. NMR 1H $\left(\mathrm{CHCl}_{3}\right), \delta(\mathrm{ppm}): 8.046$ (s, 2H, HTh), 7.45-7.42 (m, 4H, HPh), 7.38-7.28 (m, $6 \mathrm{H}, \mathrm{HPh})$. NMR 13C $\left(\mathrm{CHCl}_{3}\right), \delta(\mathrm{ppm}): 153.5,141.7,139.3,129.8(4 \mathrm{C}), 128.9,128.2$ (4C), 117.7.

IR (cm-1): 3085, 2965, 2928, 2161, 1980, 1682, 1497, 1442, 1414, 1376, 1357, 1318, 1274, 1227, 1199, 1156, 1127, 1074, 1055, 1023, 970, 919, 859, 839, 815, 770, 725. 
UV $\left(\mathrm{CHCl}_{3}\right)$ 10-4 M, $\lambda \max : 347 \mathrm{~nm}$.

MS (EI) $m / z(\%): 288.1(100, M+), 81.9$ (79), 185.1 (45). MSHR (EI): M+ Calculated 288.0716; Found 288.0717.

\section{2,3-Bis(4-methoxyphenyl)thieno[3,4-b]pyrazine 3c ( $\mathrm{Z}=p$-C6H4OMe)}

The crude product, synthesized by method 1 , is purified by flash chromatography using cyclohexane/ $\mathrm{CH}_{2} \mathrm{Cl}_{2}$ as the eluent (75/25-0/100) to obtain 3c (430 mg, $\left.22 \%\right)$ as a burgundy powder.

NMR 1H $\left(\mathrm{CHCl}_{3}\right), \delta(\mathrm{ppm}): 7.98$ (s, 2H, HTh), 7.42-7.38 (m, 4H, HPh), 6.86-6.83 (m, 4H, HPh), 3.82 (s, 6H, HOMe). NMR 13C $\left(\mathrm{CHCl}_{3}\right), \delta$ (ppm): 160.3, 153.1, 141.7, 131.8, 131.2 (4C), 117.1, $113.8(4 \mathrm{C}), 55.4$.

IR (cm-1): 3065, 2834, 1605, 1575, 1513, 1503, 1457, 1438, 1413, 1363, 1303, 1282 , $1246,1173,1108,1025,970,861,831$.

UV $\left(\mathrm{CHCl}_{3}\right) 10-4 \mathrm{M}, \lambda \max : 378 \mathrm{~nm}$.

MS (EI) m/z (\%): 348.2 (100, M+), 215.1 (63), 81.9 (62), 200.0 (23). MSHR (El): M+ Calculated 348.0927; Found 348.0924.

\section{2,3-Bis(4-fluorophenyl)thieno[3,4-b]pyrazine 3d ( $\mathrm{Z}=p$-C6H4F)}

The crude product is purified by flash chromatography using $\mathrm{CH}_{2} \mathrm{Cl}_{2}$ as the eluent to obtain 3d (method 1: $200 \mathrm{mg}, 43 \%$, method 2: $80 \mathrm{mg}, 30 \%$ ), as a pink powder.

NMR 1H $\left(\mathrm{CHCl}_{3}\right), \delta(\mathrm{ppm}): 8.03$ (s, 2H, HTh), 7.43-7.38 (m, 4H, HPh), 7.04-6.99 (m, 4H, $\mathrm{HPh})$. NMR 13C $\left(\mathrm{CHCl}_{3}\right), \delta(\mathrm{ppm}): 163.3(\mathrm{~d}, 1 \mathrm{JC}-\mathrm{F}=249.6 \mathrm{~Hz}), 152.2,141.6,135.2,131.7$ $(\mathrm{d}, J C-F=8.3 \mathrm{~Hz}, 4 \mathrm{C}), 117.9,115.6(\mathrm{~d}, J C-F=21.8 \mathrm{~Hz}, 4 \mathrm{C})$.

NMR 19F $\{1 \mathrm{H}\}\left(\mathrm{CHCl}_{3}\right), \delta(\mathrm{ppm}): 111.6$.

IR (cm-1): 3067, 2162, 1898, 1598, 1507, 1360, 1282, 1262, 1224, 1164, 1156, 1099, $1052,1014,972,862,838$.

UV $\lambda \max \left(\mathrm{CHCl}_{3}\right)$ 10-4 M, $\lambda \max : 348 \mathrm{~nm}$.

MS (EI) $\mathrm{m} / \mathrm{z}$ (\%): 324.1 (100, M+). MSHR (EI): M+ Calculated 324.0527; Found 324.0525.

\section{General procedure for the preparation of thienopyrazines 7a-f}

Method 1: In a $25 \mathrm{~mL}$ two-necked round-bottom flask were added under nitrogen $200 \mathrm{mg}$ $(0.718 \mathrm{mmol}, 1.5 \mathrm{eq}$.) of diamine 6 and $0.478 \mathrm{mmol}$ (1.0 eq.) of the 1,2-diketone 2 in $6.0 \mathrm{~mL}$ of absolute ethanol. The mixture was then stirred and refluxed for 4 days. After evaporation of the solvent under reduced pressure, the residue was purified by flash chromatography.

Method 2: In an adequate microwaves vessel were added under nitrogen $246 \mathrm{mg}(0.886$ $\mathrm{mmol}, 1.0$ eq.) of diamine 6 and $0.886 \mathrm{mmol}$ (1.0 eq.) of the 1,2-diketone 2 in $4.0 \mathrm{~mL}$ of absolute ethanol. The reaction mixture was stirred and warmed up at $150{ }^{\circ} \mathrm{C}$ for 20 min under microwaves irradiation ( $200 \mathrm{~W}$ ). After evaporation of the solvent under reduced pressure, the residue was purified by flash chromatography.

\section{2,3-Diethyl-5,7-di(thiophen-2-yl)thieno[3,4-b]pyrazine 7a (Z = Et)}

The crude product, synthesized by method 2 , is purified by flash chromatography using cyclohexane/ $\mathrm{CH}_{2} \mathrm{Cl}_{2}$ as the eluent (75/25 to 50/50) to obtain 7a (200 mg, $63 \%$ ) as a red powder.

NMR 1H $\left(\mathrm{CHCl}_{3}\right), \delta(\mathrm{ppm}): 7.61(\mathrm{dd}, J=3.7 \mathrm{~Hz}, J=1.1 \mathrm{~Hz}, 2 \mathrm{H}, \mathrm{HTh}), 7.36$ (dd, $J=5.1$ $\mathrm{Hz}, J=1.1 \mathrm{~Hz}, 2 \mathrm{H}, \mathrm{HTh}$ ), 7.10 (dd, $J=5.1 \mathrm{~Hz}, J=3.7 \mathrm{~Hz}, 2 \mathrm{H}, \mathrm{HTh}$ ), 2.95 (q, $J=7.2 \mathrm{~Hz}, 4 \mathrm{H}$, $\mathrm{CH} 2 \mathrm{H}), 1.49(\mathrm{t}, J=7.2 \mathrm{~Hz}, 6 \mathrm{H}, \mathrm{CH} 3 \mathrm{H})$. NMR 13C $\left(\mathrm{CHCl}_{3}\right), \delta(\mathrm{ppm}): 156.9,137.9,135.0$, 127.1, 126.2, 123.9, 123.7, 28.4, 10.9.

IR (cm-1): 3108, 3063, 2968, 2930, 2897, 2578, 2161, $1790,1706,1633,1573,1537,1497,1454,1443,1427,1414,1374,1337,1262,1240,1225$, $1201,1160,1127,1077,1053,1023,972,929,908,847,830,812,798,781,741$. 
UV $\left(\mathrm{CHCl}_{3}\right)$ 10-4 M, $\lambda$ max: $504 \mathrm{~nm}$.

MS (EI) m/z (\%): 355.9 (100, M+), 57.0 (39), 71.0 (26). MSHR (EI): M+ Calculated 356.0470; Found 356.0471.

\section{2,3-Diphenyl-5,7-di(thiophen-2-yl)thieno[3,4-b]pyrazine $7 \mathrm{~b}(\mathrm{Z}=\mathrm{Ph})$}

The crude product, synthesized by method 1 , is purified by flash chromatography using cyclohexane/ $\mathrm{CH}_{2} \mathrm{Cl}_{2}$ as the eluent $(50 / 50$ to $0 / 100)$ to obtain $7 \mathrm{~b}(210 \mathrm{mg}, 65 \%)$ as a pink powder.

NMR 1H $\left(\mathrm{CHCl}_{3}\right), \delta(\mathrm{ppm}): 7.68(\mathrm{dd}, J=3.7 \mathrm{~Hz}, J=1.1 \mathrm{~Hz}, 2 \mathrm{H}, \mathrm{HTh}), 7.62-7.58(\mathrm{~m}$, 4H, HTh et HPh), 7.41-7.34 (m, 8H, HPh et HPh), 7.12 (dd, $J=5.1 \mathrm{~Hz}, J=3.7 \mathrm{~Hz}, 2 \mathrm{H}, \mathrm{HTh}$ ). NMR 13C $\left(\mathrm{CHCl}_{3}\right), \delta$ (ppm): 153.0, 147.4, 139.1, 134.8, 130.2, 129.2, 128.2, 127.5, 126.8, 125.0, 124.8.

IR (cm-1): 3056, 2161, 1979, 1637, 1498, 1442, 1427, 1409, 1355, 1341, 1265, 1246 , 1224, 1155, 1086, 1050, 1026, 984, 924, 908, 844.

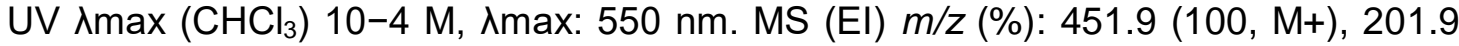
(15). MSHR (El): M+ Calculated 452.0470; Found 452.0473.

\section{2,3-Bis(4-methoxyphenyl)-5,7-di(thiophen-2-yl)thieno[3,4-b]pyrazine $7 \mathrm{c} \quad(\mathrm{Z}=\mathrm{p}$ - C6H4OMe)}

The crude product, synthesized by method 1 , is purified by flash chromatography using $\mathrm{CH}_{2} \mathrm{Cl}_{2} / \mathrm{EtOAc}$ as the eluent $(100 / 0-25 / 75)$ to obtain $7 \mathrm{c}(100 \mathrm{mg}, 41 \%)$ as a burgundy powder. NMR $1 \mathrm{H}\left(\mathrm{CHCl}_{3}\right), \delta(\mathrm{ppm}): 7.64(\mathrm{dd}, J=3.7 \mathrm{~Hz}, J=1.1 \mathrm{~Hz}, 2 \mathrm{H}, \mathrm{HTh}), 7.58(\mathrm{~d}, J=8.9$ $\mathrm{Hz}, 4 \mathrm{H}, \mathrm{HPh}$ ), 7.38 (dd, $J=5.1 \mathrm{~Hz}, J=1.1 \mathrm{~Hz}, 2 \mathrm{H}, \mathrm{HTh}), 7.11(\mathrm{dd}, J=5.1 \mathrm{~Hz}, J=3.7 \mathrm{~Hz}, 2 \mathrm{H}$, $\mathrm{HTh}), 6.88(\mathrm{~d}, J=8.9 \mathrm{~Hz}, 4 \mathrm{H}, \mathrm{HPh}), 3.85(\mathrm{~s}, 6 \mathrm{H}, \mathrm{HOMe})$. NMR 13C $\left(\mathrm{CHCl}_{3}\right), \delta(\mathrm{ppm}): 160.6$, 152.6, 134.9, 131.82, 131.65, 127.4, 126.6, 124.5, 113.7, 105.7, 94.7, 89.7, 55.5.

IR (cm-1): 3073, 2995, 2958, 2927, 2835, 2049, 1600, 1573, 1509, 1456, 1440, 1410 , 1354, 1289, 1245, 1170, 1078, 1028, 982, 923, 824. UV $\lambda \max \left(\mathrm{CHCl}_{3}\right) 10-4 \mathrm{M}, \lambda \max : 546 \mathrm{~nm}$. MS (EI) m/z (\%): 511.9 (100, M+). MSHR (EI): M+ Calculated 512.0683; Found 512.0683.

\section{2,3-Bis(4-fluorophenyl)-5,7-di(thiophen-2-yl)thieno[3,4-b]pyrazine 7d ( $\mathrm{Z}=p$-C6H4F)}

The desired product, synthesized by method 2 , appeared as a pink solid in the reaction vessel, were filtered and washed with cold absolute ethanol and no extra flash chromatography purification was necessary. $\mathbf{7 d}$ was obtained $(230 \mathrm{mg}, 53 \%)$ as a pink powder.

NMR $1 \mathrm{H}\{19 \mathrm{~F}\}\left(\mathrm{CHCl}_{3}\right), \delta(\mathrm{ppm}): 7.66$ (dd, $\left.J=3.7 \mathrm{~Hz}, J=1.1 \mathrm{~Hz}, 2 \mathrm{H}, \mathrm{HTh}\right), 7.60-7.55$ (m, 4H, HPh), 7.40 (dd, $J=5.1 \mathrm{~Hz}, J=1.1 \mathrm{~Hz}, 2 \mathrm{H}, \mathrm{HTh}$ ), 7.13 (dd, $J=5.1 \mathrm{~Hz}, J=3.7 \mathrm{~Hz}, 2 \mathrm{H}$, HTh), 7.09-7.03 (m, 4H, HPh). NMR 13C $\left(\mathrm{CHCl}_{3}\right), \delta(\mathrm{ppm}): 163.5(\mathrm{~d}, 1 J C-F=250.0 \mathrm{~Hz}), 151.6$, 137.3, $135.0(\mathrm{~d}, 4 J C-F=3.3 \mathrm{~Hz}), 134.5,132.0(\mathrm{~d}, 3 J C-F=8.4 \mathrm{~Hz}, 4 \mathrm{C}), 127.4,126.9$,

$125.1,124.7,115.46(\mathrm{~d}, 2 J C-F=21.8 \mathrm{~Hz}, 4 \mathrm{C}) . \mathrm{NMR} 19 \mathrm{~F}\{1 \mathrm{H}\}\left(\mathrm{CHCl}_{3}\right), \delta(\mathrm{ppm}): 111.44$.

IR (cm-1): 3100, 3069, 1900, 1642, 1601, 1507, 1404, 1353, 1273, 1231, 1154, 1096, 1077, 1056, 1011, 986, 959, 831. UV $\left(\mathrm{CHCl}_{3}\right)$ 10-4 M, גmax: $550 \mathrm{~nm}$. MS (EI) $\mathrm{m} / \mathrm{z}$ (\%): 487.8 (100, M+), 201.9 (24). MSHR (El): M+ Calculated 488.0282; Found 488.0281.

\section{2,3-Di(pyridin-2-yl)-5,7-di(thiophen-2-yl)thieno[3,4-b]pyrazine 7e (Z = 2-pyridyl)}

The crude product, synthesized by method 2 , is purified by flash chromatography using $\mathrm{CH}_{2} \mathrm{Cl}_{2} / \mathrm{EtOAc}$ as the eluent $(75 / 25)$ to obtain $7 \mathrm{e}(100 \mathrm{mg}, 25 \%)$ as a dark pink powder.

NMR $1 \mathrm{H}\left(\mathrm{CHCl}_{3}\right), \delta$ (ppm): 8.29-8.23 (m, 4H, HPy), 7.95-7.87 (m, 2H, HPy), 7.70 (dd, $J=3.7 \mathrm{~Hz}, J=1.1 \mathrm{~Hz}, 2 \mathrm{H}, \mathrm{HTh}), 7.41$ (dd, $J=5.1 \mathrm{~Hz}, J=1.1 \mathrm{~Hz}, 2 \mathrm{H}, \mathrm{HTh}), 7.25-7.21(\mathrm{~m}, 2 \mathrm{H}$, HPy), 7.13 (dd, $J=5.1 \mathrm{~Hz}, J=3.7 \mathrm{~Hz}, 2 \mathrm{H}, \mathrm{HTh}$ ).

IR (cm-1): 3022, 2091, 2969, 2930, 2161, 1583, 1565, 1497, 1460, 1428, 1415, 1374 , $1342,1301,1275,1240,1226,1202,1128,1090,1052,1007,913,844,806,781,740$. UV $\left(\mathrm{CHCl}_{3}\right)$ 10-4 M, Amax: $551 \mathrm{~nm}$. MS (El) $\mathrm{m} / \mathrm{z}(\%): 453.8$ (100, $\mathrm{M}+$ ).

MSHR (EI): M+ Calculated 454.0375; Found 454.0373. 


\section{0,12-Di(thiophen-2-yl)dibenzo[f,h]thieno[3,4-b]quinoxaline $7 f(Z=2,2$ '-diphenyl)}

The crude product, synthesized by method 2 , is purified by flash chromatography using cyclohexane/ $\mathrm{CH}_{2} \mathrm{Cl}_{2}$ as the eluent $(50 / 50$ to $0 / 100)$ to obtain $7 \mathbf{f}(210 \mathrm{mg}, 53 \%)$ as a green powder.

NMR $1 \mathrm{H}\left(250 \mathrm{MHz}, \mathrm{CHCl}_{3}\right), \delta(\mathrm{ppm}):$ 7.51-7.36 (m, 10H, HTh et HPh), 7.25-7.21 (m, 2H, HTh), 7.14-7.11 (m, 2H, HTh). NMR 13C (CDCl3), $\delta$ (ppm): 153.5, 138.8, 137.7, 136.1, $130.14,130.01,129.4,128.3,124.37,124.23,114.9$.

IR (cm-1): 3101, 3063, 2968, 2930, 2897, 2734, 2578, 2161, 1790, 1705, 1633, 1572 , $1537,1497,1454,1443,1427,1414,1373,1337,1262,1239,1225,1200,1159,1127,1053$, $1022,972,929,908,847,830,812,798,781,741$.

UV $\left(\mathrm{CHCl}_{3}\right)$ 10-4 M, $\lambda$ max: $630 \mathrm{~nm}$. 450.0313

MS (EI) m/z (\%): 449.8 (100, M+). MSHR (EI): M+ Calculated 450.0314; Found

\section{Thienopyrazines $8 b-d$ and $8 f$}

5,7-Bis(5-bromothiophen-2-yl)-2,3-diphenylthieno[3,4-b]pyrazine 8b ( $=\mathbf{P h})$

In a $250 \mathrm{~mL}$ two-necked round-bottom flask were added under nitrogen $1.67 \mathrm{~g} \mathrm{(3.83}$ mmol, 1.0 eq.) of diamine 9 and $804 \mathrm{mg} \mathrm{(3.83} \mathrm{mmol,} 1.0$ eq.) of diphenylethanedione (benzil) $\mathbf{2 b}$ in $95 \mathrm{~mL}$ of glacial acetic acid. The mixture was then stirred and warmed up at $60{ }^{\circ} \mathrm{C}$ for 26 h. After cooling the reaction mixture to room temperature, the pink precipitate was filtered off on büchner, washed with cold absolute ethanol and dried under vacuum. Thienopyrazine $\mathbf{8 b}$ was obtained as a pink powder $(1.23 \mathrm{~g}, 53 \%)$.

NMR 1H $\left(\mathrm{CDCl}_{3}\right), \delta(\mathrm{ppm}):$ 7.57-7.54 (m, 3H, HPh), 7.40-7.33 (m, 6H, HPh), 7.30 (d, $J=4.0 \mathrm{~Hz}, 2 \mathrm{H}, \mathrm{HTh}), 7.04$ (d, $J=4.0 \mathrm{~Hz}, 2 \mathrm{H}, \mathrm{HTh})$. NMR 13C (CDCl3), $\delta$ (ppm): 153.5, 138.8, $137.7,136.1,130.14,130.01,129.4,128.3,124.37,124.23,114.9$.

IR (cm-1): 3050, 1709, 1501, 1426, 1349, 1319, 1271, 1246, 1233, 1208, 1179, 1088, 1062, 1025, 999, 984, 970, 899, 854, 809, 781, 771, 766, 729, 716, 699, 689, 665.

MS (EI) m/z (\%): 609 (14), 430 (27), 413 (30), 178 (75), 161 (70), 143 (100). MSHR (El): $M+$ Calculated 607.8680; Found 607.8688.

\section{5,7-Bis(5-bromothiophen-2-yl)-2,3-bis(4-methoxyphenyl)thieno[3,4-b]pyrazine 8c $(\mathrm{Z}=p-\mathrm{C} 6 \mathrm{H} 4 \mathrm{OMe})$}

In a $250 \mathrm{~mL}$ two-necked round-bottom flask were added under nitrogen $1.67 \mathrm{~g} \mathrm{(3.83}$ mmol, 1.0 eq.) of diamine 9 and $1.03 \mathrm{~g}$ (3.83 mmol, 1.0 eq.) of 1,2-bis(4methoxyphenyl)ethane-1,2-dione $2 \mathrm{c}$ in $95 \mathrm{~mL}$ of glacial acetic acid. The mixture was then stirred and warmed up at $60^{\circ} \mathrm{C}$ for $36 \mathrm{~h}$. After cooling the reaction mixture to room temperature, the burgundy precipitate was filtered off on büchner, washed with cold absolute ethanol and dried under vacuum. Thienopyrazine $8 \mathrm{c}$ was obtained as a burgundy powder $(1.21 \mathrm{~g}, 47 \%)$.

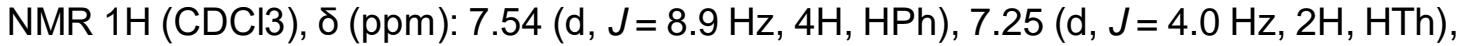
$7.03(\mathrm{~d}, J=4.0 \mathrm{~Hz}, 2 \mathrm{H}, \mathrm{HTh}), 6.89(\mathrm{~d}, J=8.9 \mathrm{~Hz}, 4 \mathrm{H}, \mathrm{HPh}), 3.86(\mathrm{~s}, 6 \mathrm{H}, \mathrm{OCH} 3)$. NMR 13C (CDCl3), $\delta(p p m): ~ 160.8,153.1,137.6,136.2,131.67,131.49,129.9,123.88,123.72,114.6$, 113.8, 55.5.

IR (cm-1): 2931, 2836, 2549, 2162, 2050, 1756, 1704, 1604, 1575, 1512, 1454, 1427 , $1412,1362,1316,1290,1247,1177,1110,1078,1061,1028,1012,984,899,835,813,782$, $759,735,694,652$.

MS (APCl) m/z (\%): 668 (5, M+), 647 (50), 470 (55), 288 (100). MSHR (APCI): M+ Calculated 668.8970; Found 668.9003.

\section{5,7-Bis(5-bromothiophen-2-yl)-2,3-bis(4-fluorophenyl)thieno[3,4-b]pyrazine $8 d$ (Z = p- C6H4F)}

In a $100 \mathrm{~mL}$ two-necked round-bottom flask were added under nitrogen $439 \mathrm{mg}(1.01$ $\mathrm{mmol}, 1.0$ eq.) of diamine 9 and $247 \mathrm{mg}$ (1.01 mmol, 1.0 eq.) of 1,2-bis(4-fluorophenyl)ethane1,2-dione $\mathbf{2 d}$ in $25 \mathrm{~mL}$ of glacial acetic acid. The mixture was then stirred and warmed up at $60^{\circ} \mathrm{C}$ for $36 \mathrm{~h}$. After cooling the reaction mixture to room temperature, the pink precipitate was filtered off on büchner, washed with cold absolute ethanol and dried under vacuum. 
Thienopyrazine $8 \mathbf{d}$ was obtained as a pink powder (580 $\mathrm{mg}, 89 \%)$.

NMR 1H $\{19 \mathrm{~F}\}(\mathrm{CDCl} 3), \delta(\mathrm{ppm}): 7.56-7.52(\mathrm{~m}, 4 \mathrm{H}, \mathrm{HPh}), 7.29$ (d, J=4.0 Hz, 2H, HTh), 7.10$7.04(\mathrm{~m}, 6 \mathrm{H}$, HTh et HPh). NMR 13C (CDCl3), $\delta(\mathrm{ppm}): 163.6(\mathrm{~d}, 1 \mathrm{JF}-\mathrm{C}=250.5 \mathrm{~Hz}), 152.1$, 137.4, 135.8, $134.7(\mathrm{~d}, 4 J F-C=3.5 \mathrm{~Hz}), 132.0(\mathrm{~d}, 3 J F C=8.4 \mathrm{~Hz}), 130.0,124.4,124.2,115.6$ $(\mathrm{d}, 2 J F-C=21.8 \mathrm{~Hz}), 115.0 . \mathrm{NMR} 19 \mathrm{~F}\{1 \mathrm{H}\}(\mathrm{CDCl} 3), \delta(\mathrm{ppm}): 111.05$.

IR (cm-1): 3233, 2162, 1654, 1600, 1507, 1429, 1403, 1352, 1315, 1299, 1266, 1248, $1228,1155,1096,1076,1064,1012,983,968,832,815,798,777,751,728,687$.

MS (APCI) m/z (\%): $644(40, M+), 413$ (20). MSHR (APCI): M+ Calculated 644.8570; Found 644.8599.

\section{0,12-Bis(5-bromothiophen-2-yl)dibenzo[f,h]thieno[3,4-b]quinoxaline $8 f$ ( $Z=2,2^{\prime}-$ diphenyl)}

In a $250 \mathrm{~mL}$ two-necked round-bottom flask were added under nitrogen $1.67 \mathrm{~g} \mathrm{(3.83}$ mmol, 1.0 eq.) of diamine 9 and $797 \mathrm{mg}$ (3.83 mmol, 1.0 eq.) of 9,10-phenanthrenedione $2 \mathrm{f}$ in $95 \mathrm{~mL}$ of glacial acetic acid. The mixture was then stirred and warmed up at $60{ }^{\circ} \mathrm{C}$ for $36 \mathrm{~h}$. After cooling the reaction mixture to room temperature, the green precipitate was filtered off on Büchner, washed with cold absolute ethanol and dried under vacuum.

Thienopyrazine $8 \mathrm{f}$ was obtained as a green powder $(1.27 \mathrm{~g}, 55 \%)$. Due to the poor solubility of the product in common organic solvents, no NMR spectra could be obtained.

IR (cm-1): 3348, 3066, 2162, 1729, 1599, 1499, 1473, 1447, 1425, 1411, 1350, 1316 , $1300,1240,1229,1208,1166,1128,1106,1088,1065,1044,966,899,869,785,765,721$, $690,664$.

MS (APCl) m/z (\%): $608(25,[\mathrm{M}+\mathrm{H}]+), 530$ (42), 451 (100). MSHR (APCI): M+ Calculated 606.8602; Found 602.8627.

\section{1-(Thiophen-2-yl)-4-(5-(tributylstannyl)thiophen-2-yl)-2,5-bis(2-ethylhexyloxy)benzene 11 [33]}

To a solution of 2,2'-(2,5-bis((2-ethylhexyl)oxy)-1,4-phenylene)dithiophene (2.23 mmol, $1.11 \mathrm{~g}$ ) in $20 \mathrm{~mL}$ of anhydrous THF was added dropwise at $-60^{\circ} \mathrm{C}$ under nitrogen $n$-butyllithium (2.23 mmol, $1.4 \mathrm{~mL}, 1.6 \mathrm{M}$ in hexanes). The mixture was slowly warmed to $0^{\circ} \mathrm{C}$. After cooling to $-10^{\circ} \mathrm{C}$, tributyltin chloride $(2.29 \mathrm{mmol}, 0.62 \mathrm{~mL})$, was added in one portion and the solution was allowed to warm to room temperature overnight.

Subsequently, the solvent was evaporated under reduced pressure and the medium was dissolved in dichloromethane, filtrated on celite, and then concentrated to give $\mathbf{1 1}$ as a brown oil. This product was used in the next step without further purification.

NMR 1H (CDCl3), $\delta(p p m): 7.65(\mathrm{~d}, J=3.2 \mathrm{~Hz}, 1 \mathrm{H}, \mathrm{HTh}), 7.53(\mathrm{dd}, J=4.0 \mathrm{~Hz}, J=1.2$ $\mathrm{Hz}, 1 \mathrm{H}, \mathrm{HTh}$ ), 7.33 (dd, $J=5.2 \mathrm{~Hz}, J=1.2 \mathrm{~Hz}, 1 \mathrm{H}, \mathrm{HTh}$ ), 7.26 (m, 2H, HPh), 7.16 (d, J=3.6 $\mathrm{Hz}, 1 \mathrm{H}, \mathrm{HTh}$ ), 7.09 (dd, $J=4.8 \mathrm{~Hz}, J=3.6 \mathrm{~Hz}, 1 \mathrm{H}, \mathrm{HTh}$ ), 3.98 (d, $J=5.6 \mathrm{~Hz}, 4 \mathrm{H}, \mathrm{O}-\mathrm{CH} 2), 1.85$ (quint, $2 \mathrm{H}, \mathrm{CH}), 1.67-1.28(\mathrm{~m}, 28 \mathrm{H}, \mathrm{CH} 2), 1.13(\mathrm{~m}, 6 \mathrm{H}, \mathrm{CH} 2), 0.97-0.88(\mathrm{~m}, 21 \mathrm{H}, \mathrm{CH} 3)$.

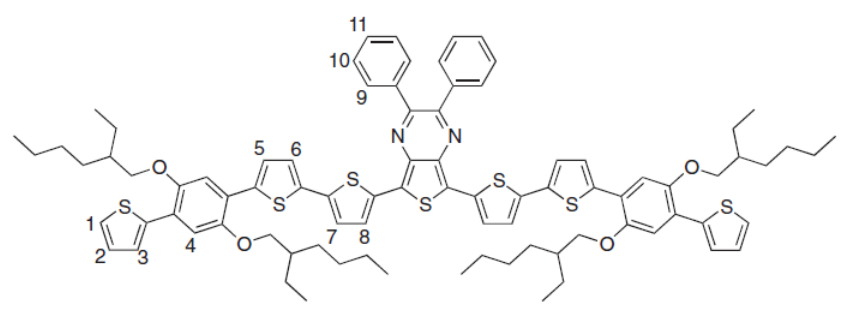

5,7-Bis(5'-(2,5-bis((2-ethylheptyl)oxy)-4-(thiophen-2-yl)phenyl)-[2,2'-bithiophen]-5-yl)2,3- diphenylthieno[3,4-b]pyrazine (DAD system 1b) - Second synthetic strategy

In a $50 \mathrm{~mL}$ two-necked round-bottom flask were added under nitrogen $200 \mathrm{mg}(0.327$ $\mathrm{mmol}, 1.0$ eq.) of $8 \mathrm{~b}, 534 \mathrm{mg}(0.679 \mathrm{mmol}, 2.1$ eq. $)$ of the monostannylated derivative 11 and $15 \mathrm{mg}\left(0.013 \mathrm{mmol}, 0.04\right.$ eq.) of $\mathrm{PdO}\left(\mathrm{PPh}_{3}\right)_{4}$ in $3.0 \mathrm{~mL}$ of dry and degassed solvents (THF/DMF 1/1). The mixture was then stirred and warmed up at $80^{\circ} \mathrm{C}$ for $48 \mathrm{~h}$. After cooling the reaction mixture to room temperature, a saturated $\mathrm{NH}_{4} \mathrm{~F}$ solution was added. The solution was 
extracted with $3 \times 50 \mathrm{~mL}$ of diethyl ether; the organic phases were assembled, washed with brine and dried over $\mathrm{MgSO}_{4}$. The solvent was evaporated under reduced pressure and the residue was purified on silica by flash chromatography using cyclohexane/ $\mathrm{CH}_{2} \mathrm{Cl}_{2}(100 / 0-$ $50 / 50$ ) as the eluent. 12b was obtained as a green powder (240 mg, $51 \%$ ).

NMR 1H (C6D6), $\delta(p p m): 7.62-7.60(\mathrm{~m}, 8 \mathrm{H}, \mathrm{H} 1$ et $\mathrm{H} 9), 7.50(\mathrm{~d}, J=3.8 \mathrm{~Hz}, 2 \mathrm{H}$, $\mathrm{H} 5,6,7,8), 7.39$ (s, 4H, H4), 7.24 (d, J=3.8 Hz, 2H, H5,6,7,8), 7.22 (d, J=3.8 Hz, 2H, H5,6,7,8), 7.14-7.11 (m, 6H, H10,11), $7.08(\mathrm{dd}, J=5.2, J=1.2 \mathrm{~Hz}, 2 \mathrm{H}, \mathrm{H} 3), 6.97(\mathrm{dd}, J=5.2, J=3.6$ $\mathrm{Hz}, 2 \mathrm{H}, \mathrm{H} 2), 3.86(\mathrm{t}, \mathrm{J}=5.0 \mathrm{~Hz}, 8 \mathrm{H}, \mathrm{O}-\mathrm{CH} 2), 1.70-1.53(\mathrm{~m}, 8 \mathrm{H}, \mathrm{CH} 2-\mathrm{CH} 3), 1.36-1.25(\mathrm{~m}$,

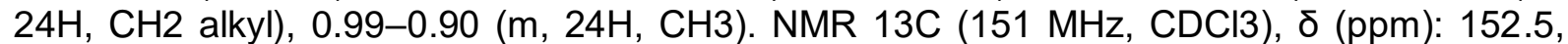
149.3, 149.3, 139.3, 139.0, 138.8, 137.9, 137.0, 136.9, 133.6, 130.1, 128.9, 128.0, 126.7, $126.1,125.8,125.6,125.3,124.8,124.7,123.8,123.7,123.2,122.4,112.5,111.8,71.7,71.6$, $39.9,39.9,31.0,30.9,29.5,29.4,24.4,24.4,23.5,23.5,14.4,14.4,11.5,11.5$.

IR (cm-1): 3062, 2954, 2920, 2854, 2160, 2027, 1737, 1603, 1532, 1479, 1462, 1437, 1400, 1378, 1355, 1263, 1209, 1069, 1027, 985, 927, 844, 778, 768, 698.

UV $\left(\mathrm{CHCl}_{3}\right)$ 10-4 M, $\lambda$ max: $648 \mathrm{~nm}$.

MS (MALDI) m/z (\%): 1445.5 (100, M+), 1030 (8), 949 (7).

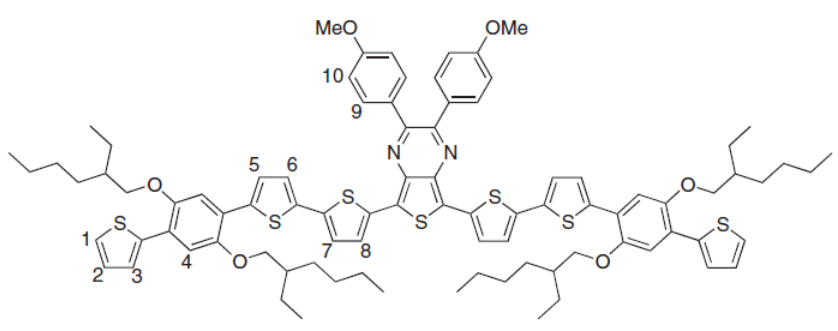

\section{5,7-Bis(5'-(2,5-bis((2-ethylheptyl)oxy)-4-(thiophen-2-yl)phenyl)-[2,2'-bithiophen]-5-yl)- 2,3-bis(4- methoxyphenyl)thieno[3,4-b]pyrazine (DAD system 2c)}

In a $50 \mathrm{~mL}$ two-necked round-bottom flask were added under nitrogen $200 \mathrm{mg}(0.298$ mmol, 1.0 eq.) of $8 \mathrm{c}, 517 \mathrm{mg}(0.656 \mathrm{mmol}, 2.2 \mathrm{eq}$.) of the monostannylated derivative 11 and $15 \mathrm{mg}(0.013 \mathrm{mmol}, 0.04$ eq. $)$ of $\mathrm{PdO}\left(\mathrm{PPh}_{3}\right)_{4}$ in $3.0 \mathrm{~mL}$ of dry and degassed solvent (THF/DMF 1/1). The mixture was then stirred and warmed up at $65^{\circ} \mathrm{C}$ for $48 \mathrm{~h}$. After cooling the reaction mixture to room temperature, a saturated $\mathrm{NH}_{4} \mathrm{~F}$ solution was added $(20 \mathrm{~mL})$. The solution was extracted with $3 \times 50 \mathrm{~mL}$ diethyl ether, the organic phases were assembled, washed with brine and dried over $\mathrm{MgSO}_{4}$. The solvent was evaporated under reduced pressure and the residue was purified on silica by flash chromatography using cyclohexane/ $\mathrm{CH}_{2} \mathrm{Cl}_{2}(100 / 0-50 / 50)$ as the eluent. 12c was obtained as a red powder (35 $\mathrm{mg}, 10 \%)$.

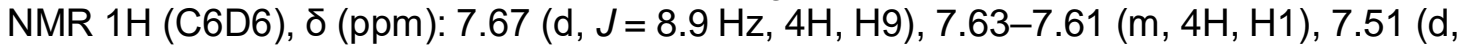
$J=3.9 \mathrm{~Hz}, 2 \mathrm{H}, \mathrm{H} 5,6,7,8), 7.40$ (s, 4H, H4), 7.29 (d, $J=3.9 \mathrm{~Hz}, 2 \mathrm{H}, \mathrm{H} 5,6,7,8), 7.26$ (d, $J=3.9$ $\mathrm{Hz}, 2 \mathrm{H}, \mathrm{H} 5,6,7,8), 7.07$ (dd, $J=5.1,1.2 \mathrm{~Hz}, 2 \mathrm{H}, \mathrm{H} 3$ ), 6.97 (dd, $J=5.1,3.6 \mathrm{~Hz}, 2 \mathrm{H}, \mathrm{H} 2$ ), 6.75 (d, $J=8.9 \mathrm{~Hz}, 4 \mathrm{H}, \mathrm{H} 10), 3.86(\mathrm{t}, J=4.6 \mathrm{~Hz}, 8 \mathrm{H}, \mathrm{O}-\mathrm{CH} 2), 3.28(\mathrm{~s}, 6 \mathrm{H}, \mathrm{OMe}), 1.68-1.51$ (m, $8 \mathrm{H}, \mathrm{CH} 2-\mathrm{CH} 3), 0.99-0.90$ (m, 24H, CH2 alkyl), 1.32-1.29 (m, 24H, CH3). NMR 13C (151 MHz, C6D6), $\delta(\mathrm{ppm}): 161.3,153.1,150.6,150.5,140.4,139.5,139.3,139.1,138.3,134.9,132.8$, $132.4,128.7,127.4,127.2,126.3,126.3,125.0,124.6,124.3,123.7,114.3,113.9,113.1,72.5$, 72.3, 55.2, 40.5, 31.6, 31.5, 30.0, 29.9, 24.9, 24.8, 23.9, 23.8, 14.7, 14.7, 11.8, 11.8 .

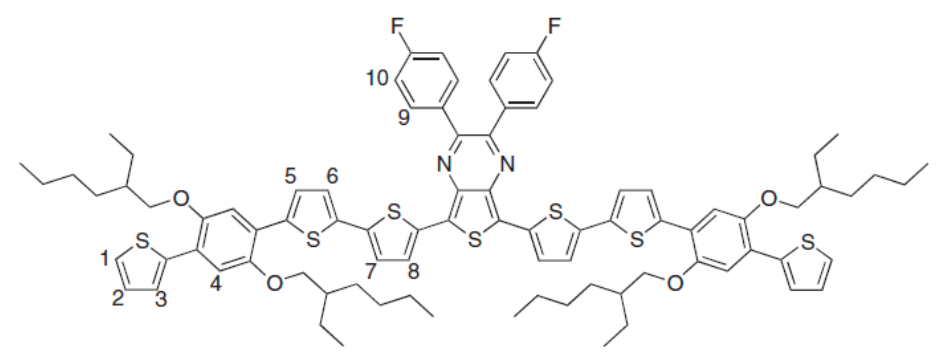




\section{5,7-Bis(5'-(2,5-bis((2-ethylheptyl)oxy)-4-(thiophen-2-yl)phenyl)-[2,2'-bithiophen]-5-yl)- 2,3-bis(4- fluorophenyl)thieno[3,4-b]pyrazine (DAD system 12d)}

In a $50 \mathrm{~mL}$ two-necked round-bottom flask were added under nitrogen $200 \mathrm{mg}(0.327$ $\mathrm{mmol}, 1.0 \mathrm{eq}$.) of $8 \mathrm{~d}, 534 \mathrm{mg}(0.679 \mathrm{mmol}, 2.2 \mathrm{eq}$.) of the monostannylated derivative 11 and $15 \mathrm{mg}\left(0.013 \mathrm{mmol}, 0.04 \mathrm{eq}\right.$.) of $\mathrm{PdO}\left(\mathrm{PPh}_{3}\right)_{4}$ in $2.0 \mathrm{~mL}$ of dry and degassed solvent (THF/DMF 1/1). The mixture was then stirred and warmed up at $65^{\circ} \mathrm{C}$ for $48 \mathrm{~h}$. After cooling the reaction mixture to room temperature, a saturated $\mathrm{NH}_{4} \mathrm{~F}$ solution was added $(20 \mathrm{~mL})$. The solution was extracted with $3 \times 50 \mathrm{~mL}$ diethyl ether, the organic phases were assembled, washed with brine and dried over $\mathrm{MgSO}_{4}$. The solvent was evaporated under reduced pressure and the residue was purified on silica by flash chromatography using cyclohexane/ $\mathrm{CH}_{2} \mathrm{Cl}_{2}(100 / 0-50 / 50)$ as the eluent. Thienopyrazine $\mathbf{1 2 d}$ was obtained as a green powder (45 mg, $10 \%)$.

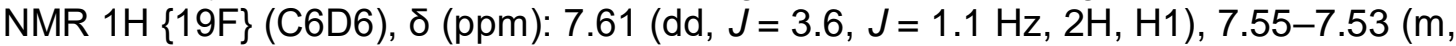
$4 \mathrm{H}, \mathrm{H} 9), 7.41-7.37(\mathrm{~m}, 8 \mathrm{H}, \mathrm{H} 4$ and $\mathrm{H} 5,6,7,8), 7.27(\mathrm{~d}, J=3.9 \mathrm{~Hz}, 2 \mathrm{H}, \mathrm{H} 5,6,7,8), 7.23(\mathrm{~d}, J=$ $3.9 \mathrm{~Hz}, 2 \mathrm{H}, \mathrm{H} 5,6,7,8), 7.08$ (dd, $J=5.1, J=1.1 \mathrm{~Hz}, 2 \mathrm{H}, \mathrm{H} 3$ ), 6.97 (dd, $J=5.1, J=3.6 \mathrm{~Hz}, 2 \mathrm{H}$, H2), 6.80-6.75 (m, 4H, H10), 3.86 (t, $J=5.2 \mathrm{~Hz}, 8 \mathrm{H}, \mathrm{O}-\mathrm{CH} 2), 1.68-1.49$ (m, 8H, CH2-CH3), 1.39-1.26 (m, 24H, CH2 alkyl), 0.98-0.91 (m, 24H, CH3). NMR 13C (151 MHz, CDCl3), $\delta$ (ppm): $163.28(\mathrm{~d}, 1 J C-F=251.0 \mathrm{~Hz}), 151.1,149.3(2 \mathrm{C}), 139.3,139.1,139.0,137.7,136.9$, $134.9(\mathrm{~d}, 4 J C-F=3.1 \mathrm{~Hz}), 132.0(\mathrm{~d}, 3 J C-F=8.2 \mathrm{~Hz}), 130.5,126.7,126.1,125.8,125.6,125.4$, 123.8, 123.6, 123.2, 122.3, $115.2(\mathrm{~d}, 2 J C-F=21.6 \mathrm{~Hz}), 115.2,114.8,112.5,111.8,71.8,71.6$, $39.9,39.9,31.0,30.9,29.5,29.4,24.4,24.4,23.5,23.5,14.4,14.4,11.5,11.5$. NMR $19 F\{1 \mathrm{H}\}$ (C6D6), ठ (ppm): 111.44.

IR (cm-1): 3066, 2955, 2922, 2856, 2161, 2039, 1711, 1601, 1532, 1508, 1486, 1459 , 1441, 1401, 1379, 1355, 1264, 1208, 1157, 1096, 1073, 1029, 986, 836, 816, 781, 728, 691. UV $\left(\mathrm{CHCl}_{3}\right)$ 10-4 M, $\lambda$ max: $660 \mathrm{~nm}$.

MS (APCl) m/z (\%): $1481(100, M+)$. MSHR (APCl): M+ Calculated 1481.5299; Found 1481.5286.

\section{5,5"'-Bis(2,5-bis((2-ethylhexyl)oxy)-4-(thiophen-2-yl)phenyl)-3",4"-dinitro- $2,2^{\prime}: 5^{\prime}, 2^{\prime \prime}: 5^{\prime \prime}, 2^{\prime \prime}: 5^{\prime \prime \prime}, 2^{\prime \prime \prime}$ - quinquethiophene 13}

In a $100 \mathrm{~mL}$ two-necked round-bottom flask were added under nitrogen $1.37 \mathrm{~g}(2.77$ mmol, 1.0 eq.) of dibrominated compound $9,4.36 \mathrm{~g}(5.54 \mathrm{mmol}, 2.0 \mathrm{eq}$.) of the monostannylated derivative 11 and $15 \mathrm{mg}(0.111 \mathrm{mmol}, 0.04$ eq. $)$ of $\mathrm{PdO}\left(\mathrm{PPh}_{3}\right)_{4}$ in $20 \mathrm{~mL}$ of dry and degassed solvent (DMF/THF 4/1). The mixture was then stirred and warmed up at 80 ${ }^{\circ} \mathrm{C}$ for $16 \mathrm{~h}$. After cooling the reaction mixture to room temperature, the mixture was filtered on celite, washed with $100 \mathrm{~mL}$ of $\mathrm{CH}_{2} \mathrm{Cl}_{2}$ and the filtrate extracted with $2 \times 100 \mathrm{~mL}$ of $\mathrm{CH}_{2} \mathrm{Cl}_{2}$. All the organic phases were assembled, washed with brine $(3 \times 100 \mathrm{~mL})$ and dried over $\mathrm{MgSO}_{4}$. After evaporation of the solvent under reduced pressure, the residue was purified on silica by flash chromatography using cyclohexane/ $\mathrm{CH}_{2} \mathrm{Cl}_{2}(100 / 0-70 / 30)$ as the eluent. Compound 13 was obtained as a red powder $(2.15 \mathrm{~g}, 30 \%)$.

NMR 1H (C6D6), $\delta(p p m): ~ 7.61(d d, J=3.7 \mathrm{~Hz}, J=1.2 \mathrm{~Hz}, 2 \mathrm{H}, \mathrm{HTh}), 7.49$ (d, $J=3.7$ $\mathrm{Hz}, 2 \mathrm{H}, \mathrm{HTh}$ ), 7.39 (s, 4H, HPh), 7.12-7.10 (d, J = $4 \mathrm{~Hz}, 2 \mathrm{H}, \mathrm{HTh}$ ), 7.08-7.04 (m, 4H, HTh), 6.98-6.94 (m, 4H, HTh), 3.87 (d, J = 5.4 Hz, 4H, O-CH2), 3.85 (d, $J=5.4 \mathrm{~Hz}, 4 \mathrm{H}, \mathrm{O}-\mathrm{CH} 2)$, 1.82-1.68 (m, 4H, CH), 1.67-1.40 (m, 16H, CH2), 1.39-1.22 (m, 16H, CH2), 0.99-0.84 (m, 24H, CH3). NMR 13C (CDCl3), $\delta$ (ppm): 149.58 (CPh-O), 149.55 (CPh-O), 144.2 (CTh), 140.7 (CTh-NO2), 139.3 (CTh), 135.5(CTh), 135.2(CTh), 133.4(CTh), 132.2(CTh), 126.9 (CHTh), 126.2 (CHTh), 126.1 (CHTh), 126.0 (CHTh), 125.6 (CHTh), 125.3 (CHTh), 124.0 (CHTh), 123.9 (CPh), 121.9 (CPh), 112.7 (CHPh), $111.9(\mathrm{CHPh}), 72.2(\mathrm{CH} 2-\mathrm{O}), 72.0(\mathrm{CH} 2-\mathrm{O}), 39.9$ $(\mathrm{CH}), 39.8(\mathrm{CH}), 31.0(\mathrm{CH} 2), 30.8(\mathrm{CH} 2), 29.4(\mathrm{CH} 2), 29.3(\mathrm{CH} 2), 24.3(\mathrm{CH} 2), 24.2(\mathrm{CH} 2)$, $23.3(\mathrm{CH} 2), 23.2(\mathrm{CH} 2), 14.28(\mathrm{CH} 3), 14.25(\mathrm{CH} 3), 11.5(\mathrm{CH} 3), 11.4(\mathrm{CH} 3)$.

IR (cm-1): 2958, 2927, 2871, 1538, 1438, 1389, 1212, 1032, 787, 694.

MS (MALDI) $m / z(\%): 1316.4\left(M_{+}, 100\right)$. 


\section{=5,5"'-Bis(2,5-bis((2-ethylhexyl)oxy)-4-(thiophen-2-yl)phenyl)-[2,2':5',2":5",2"':5'",2"'-- quinquethiophene]-3",4"-diamine 14}

In a $250 \mathrm{~mL}$ two-necked round-bottom flask were added under nitrogen $2.15 \mathrm{~g} \mathrm{(1.60}$ mmol, 1.0 eq.) of the dinitro compound 13 and $2.30 \mathrm{~g} \mathrm{(41.0} \mathrm{mmol,} 25$ eq.) of iron powder in 60 $\mathrm{mL}$ of glacial acetic acid. The mixture was then stirred and warmed up at $60^{\circ} \mathrm{C}$ for $16 \mathrm{~h}$. After cooling the reaction mixture to room temperature, the solvent was evaporated under reduced pressure and the residue is filtered on a plug of silica gel using $\mathrm{CH}_{2} \mathrm{Cl}_{2}$ as the solvent. After evaporation of the solvent under reduced pressure, $1.6 \mathrm{~g}$ of compound 14 was obtained (78 $\%)$ and was directly used in the next step because of its low stability towards air.

\section{5,7-Bis(5'-(2,5-bis((2-ethylhexyl)oxy)-4-(thiophen-2-yl)phenyl)-[2,2'-bithiophen]-5-yl)-2,3- diphenylthieno[3,4-b]pyrazine $12 b-$ Third synthetic strategy}

In a $100 \mathrm{~mL}$ two-necked round-bottom flask were added under nitrogen $636 \mathrm{mg}(0.50$ mmol, 1.0 eq.) of diamine 14 and $115 \mathrm{mg}(0.55 \mathrm{mmol}, 1.1$ eq.) of diphenylethanedione (benzyl) (2b) in $25 \mathrm{~mL}$ of glacial acetic acid and $10 \mathrm{~mL}$ of $\mathrm{CHCl}_{3}$. The mixture was then stirred and refluxed for $4 \mathrm{~h}$. After cooling the reaction mixture to room temperature, the solvent was evaporated under reduced pressure and the residue was purified on silica by flash chromatography using cyclohexane/ $\mathrm{CH}_{2} \mathrm{Cl}_{2}(80 / 20-60 / 40)$ as the eluent. Compound $\mathbf{1 2 b}$ was obtained as a pink powder (374 mg, $52 \%)$.

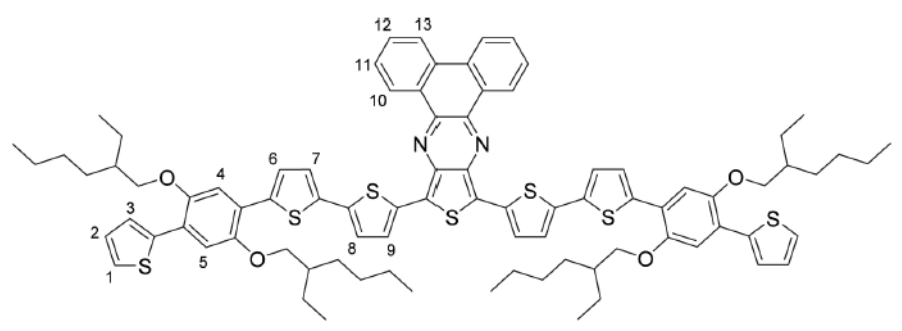

\section{0,12-Bis(5'-(2,5-bis((2-ethylhexyl)oxy)-4-(thiophen-2-yl)phenyl)-[2,2'-bithiophen]-5-} yl)dibenzo[f,h] thieno[3,4-b]quinoxaline $12 \mathrm{f}$

In a $250 \mathrm{~mL}$ two-necked round-bottom flask were added under nitrogen $1.60 \mathrm{~g} \mathrm{(1.26}$ mmol, 1.0 eq.) of diamine 14 and $275 \mathrm{mg}$ (1.32 mmol, 1.05 eq.) of 9,10-phenanthrenedione (2f) in $25 \mathrm{~mL}$ of glacial acetic acid and $10 \mathrm{~mL}$ of $\mathrm{CHCl}_{3}$. The mixture was then stirred and refluxed for $4 \mathrm{~h}$. After cooling the reaction mixture to room temperature, the solvent was evaporated under reduced pressure and the residue was purified on silica by flash chromatography using cyclohexane/ $\mathrm{CH}_{2} \mathrm{Cl}_{2}(80 / 20-60 / 40)$ as eluent. Compound $12 \mathrm{f}$ was obtained as a dark pink powder $(510 \mathrm{mg}, 28 \%)$.

NMR 1H (C6D6), $\delta(p p m): 9.03$ (dd, $J=1.0 \mathrm{~Hz}, J=7.7 \mathrm{~Hz}, 2 \mathrm{H}, \mathrm{H} 10), 7.84$ (d, $J=8.8$ $\mathrm{Hz}, 2 \mathrm{H}, \mathrm{H} 13$ ), 7.64 (dd, $J=1.0 \mathrm{~Hz}, J=2.5 \mathrm{~Hz}, 2 \mathrm{H}, \mathrm{H} 3$ ), 7.51 (d, $J=3.8 \mathrm{~Hz}, 2 \mathrm{H}, \mathrm{H} 6), 7.40$ (s, $2 \mathrm{H}, \mathrm{H} 4$ or 5), 7.39 (s, 2H, H4 or 5), 7.36 (dd, $J=7.6 \mathrm{~Hz}, J=7.7 \mathrm{~Hz}, 2 \mathrm{H}, \mathrm{H} 11$ ), 7.28 (dd, $J=$ $7.6 \mathrm{~Hz}, J=8.8 \mathrm{~Hz}, 2 \mathrm{H}, \mathrm{H} 12), 7.22(\mathrm{~d}, J=3.6 \mathrm{~Hz}, 2 \mathrm{H}, \mathrm{H} 7), 7.19$ (d, J = 3.6 Hz, 2H, H8), 7.10 (dd, $J=1.1,5.1,2 \mathrm{H}, \mathrm{H} 10), 7.00(\mathrm{~d}, J=3.6 \mathrm{~Hz}, 2 \mathrm{H}, \mathrm{H} 2), 6.98(\mathrm{~d}, J=3.6 \mathrm{~Hz}, 2 \mathrm{H}, \mathrm{H} 9), 3.96-$ $3.87(\mathrm{~m}, 8 \mathrm{H}, \mathrm{O}-\mathrm{CH} 2), 1.91-1.78(\mathrm{~m}, 4 \mathrm{H}, \mathrm{CH}), 1.75-1.42(\mathrm{~m}, 16 \mathrm{H}, \mathrm{CH} 2), 1.42-1.27(\mathrm{~m}, 16 \mathrm{H}$, $\mathrm{CH} 2), 1.2-0.88$ (m, 24H, CH3). NMR 13C (C6D6), $\delta$ (ppm): 150.4 (CPh-O), 150.3 (CPh-O), 142.7 (C=N), 140.4 (CTh), 139.2 (CTh), 138.80 (CTh), 138.78 (CTh), 138.5 (CTh), 134.8 (CTh), 132.9 (CTh), 131.4 (CAr), 130.4 (C-H12), 128.5 (CAr), 128.3 (C-H11), 127.5 (C-H10), 127.0 (C-H6), 126.2 (C-H3), 125.3 (C-H7), 124.1 (C-H2), 124.0 (C-H8), 123.8 (CPh), 123.6 (CPh), 123.2 (C-H13), 113.4 (CHPh), $112.5(\mathrm{CHPh}), 72.4(\mathrm{CH} 2-\mathrm{O}), 72.3(\mathrm{CH} 2-\mathrm{O}), 40.4(2 \mathrm{CH})$, $31.6(\mathrm{CH} 2), 31.4(\mathrm{CH} 2), 30.1(\mathrm{CH} 2), 30.0(\mathrm{CH} 2), 24.83(\mathrm{CH} 2), 24.78(\mathrm{CH} 2), 24.0(\mathrm{CH} 2), 23.9$ (CH2), $14.9(\mathrm{CH} 3), 14.8(\mathrm{CH} 3), 11.94(\mathrm{CH} 3), 11.88(\mathrm{CH} 3)$.

IR (cm-1): 3067, 2956, 2925, 2858, 1603, 1533, 1490, 1466, 1436, 1402, 1380, 1353,

1295, 1211, 1109, 1033, 846, 783, 760, 722, 693.

MS (MALDI) $m / z(\%): 1442.5(\mathrm{M}+, 100)$.

UV $\left(\mathrm{CHCl}_{3}\right)$ 10-4 M, $\lambda$ max: $739 \mathrm{~nm}$. 
Acknowledgement: We gratefully acknowledge financial support of this work provided by the French Research Council, PHC Volubilis ( $\left.{ }^{\circ} 24425 W H\right)$, CNRS-CNRST ( $\left.{ }^{\circ} 22579\right)$ and CAPES COFECUB (Ph 666/10) programs.

\section{References}

[1] T. Grassen, G. Meller, L. Li. Organic Electronics, (Ed.), A.I.P. Science, Springer, Berlin, Heidelberg (2010).

[2] H. Klauk. Organic Electronics: Materials, Manufacturing, and Applications. Wiley-VCH, Weinheim (2006).

[3] L. Dou, Y. Liu, Z. Hong, G. Li, Y. Yang. Chem. Rev. 115, 12633 (2015).

[4] R. Shinar, J. Shinar. Organic Electronics in Sensors and Biotechnology. McGraw-Hill, Inc., New York (2009).

[5] C. Zhang, P. Chen, W. Hu. Chem. Soc. Rev. 44, 2087 (2015).

[6] S. Scholz, D. Kondakov, B. Lussem, K. Leo. Chem. Rev. 115, 8449 (2015).

[7] X. Yang, G. Zhou, W. Y. Wong. Chem. Soc. Rev. 44, 8484 (2015).

[8] J. Rocali. Chem. Rev. 97, 173 (1997).

[9] W. C. Yen, B. Pal, J. S. Yang, Y. C. Hung, S. T. Lin, C. Y. Chao, W. F. Su. J. Polym. Sci. Part A: Polym. Chem. 47, 5044 (2009).

[10] S. C. Rasmussen, R. L. Schwiderski, M. E. Mulholland. Chem. Commun. 47, 11394 (2011).

[11] J. P. Nietfeld, R. L. Schwiderski, T. P. Gonnella, S. C. Rasmussen. J. Org. Chem. 76, 6383 (2011).

[12] R. Mondal, S. W. Ko, Z. N. Bao. J. Mater. Chem. 20, 10568 (2010).

[13] L. E. McNamara, N. Liyanage, A. Peddapuram, J. S. Murphy, J. H. Delcamp, N. I. Hammer. J. Org. Chem. 81, 32 (2016).

[14] P.-L. T. Boudreault, A. Najari, M. Leclerc. Chem. Mater. 23, 456 (2011).

[15] H. X. Zhou, L. Q. Yang, W. You. Macromolecules 45, 607 (2012).

[16] S. Gunes, H. Neugebauer, N. S. Sariciftci. Chem. Rev. 107, 1324 (2007).

[17] L. Ye, H. Hu, M. Ghasemi, T. Wang, B. A. Collins, J. H. Kim, K. Jiang, J. H. Carpenter, H. Li, Z. Li, T. McAfee, J. Zhao, X. Chen, J. L. Y. Lai, T. Ma, J. L. Bredas, H. Yan, H. Ade. Nat. Mater. 17, 253 (2018).

[18] M. D. Gomez-Jimenez, R. Pou-Amerigo, E. Orti. J. Chem. Phys. 131, 244105 (2009).

[19] A. S. Ozen, C. Atilgan, G. Sonmez. J. Phys. Chem. C. 111, 16362 (2007).

[20] D. D. Kenning, K. A. Mitchell, T. R. Calhoun, M. R. Funfar, D. J. Sattler, S. C. Rasmussen. J. Org. Chem. 67, 9073 (2002).

[21] Z. J. Zhao, D. D. Wisnoski, S. E. Wolkenberg, W. H. Leister, Y. Wang, C. W. Lindsley. Tetrahedron Lett. 45, 4873 (2004).

[22] S. Steinberger, A. Mishra, E. Reinold, E. Mena-Osteritz, H. Muller, C. Uhrich, M. Pfeiffer, P. Bauerle. J. Mater. Chem. 22, 2701 (2012).

[23] E. Perzon, X. J. Wang, F. L. Zhang, W. Mammo, J. L. Delgado, P. de la Cruz, O. Inganas, F. Langa, M. R. Andersson. Synth. Met. 154, 53 (2005).

[24] P. Li, O. Fenwick, S. Yilmaz, D. Breusov, D. J. Caruana, S. Allard, U. Scherf, F. Cacialli. Chem Commun (Camb). 47, 8820 (2011).

[25] S. Lois, J.-C. Flores, J.-P. Lere-Porte, F. Serein-Spirau, J. J. E. Moreau, K. Miqueu, J.-M. Sotiropoulos, P. Baylere, M. Tillard, C. Belin. Eur. J. Org. Chem. 2007, 4019 (2007).

[26] Y. J. Xia, J. Luo, X. Y. Deng, X. Z. Li, D. Y. Li, X. H. Zhu, W. Yang, Y. Cao. Macromol. Chem. Phys. 207, 511 (2006).

[27] F. L. Zhang, E. Perzon, X. J. Wang, W. Mammo, M. R. Andersson, O. Inganas. Adv. Funct. Mater. 15, 745 (2005).

[28] M. J. Frisch, G. W. Trucks, H. B. Schlegel, G. E. Scuseria, M. A. Robb, J. R. Cheeseman, G. Scalmani, V. Barone, G. A. Petersson, H. Nakatsuji, X. Li, M. Caricato, A. Marenich, J. Bloino, B. G. Janesko, R. Gomperts, B. Mennucci, H. P. Hratchian, J. V. Ortiz, A. F. Izmaylov, J. L. Sonnenberg, D. Williams-Young, F. Ding, F. Lipparini, F. Egidi, J. Goings, B. Peng, A. Petrone, T. Henderson, D. Ranasinghe, V. G. Zakrzewski, J. Gao, N. Rega, G. Zheng, W. Liang, M. Hada, M. Ehara, K. Toyota, R. Fukuda, J. Hasegawa, M. Ishida, T. Nakajima, Y. Honda, O. Kitao, H. Nakai, T. Vreven, K. Throssell, J. A. Montgomery, Jr., J. E. Peralta, F. Ogliaro, M. Bearpark, J. J. Heyd, E. Brothers, K. N. Kudin, V. N. Staroverov, T. Keith, R. Kobayashi, J. Normand, K. Raghavachari, A. Rendell, J. C. Burant, S. S. lyengar, J. Tomasi, M. Cossi, J. M. Millam, M. Klene, C. Adamo, R. Cammi, J. W. Ochterski, R. L. Martin, K. Morokuma, O. Farkas, J. B. Foresman, and D. J. Fox. Gaussian 09, Revision D.01, Gaussian, Inc., Wallingford, CT (2016). 
[29] R. G. Parr, W. Yang. Functional Theory of Atoms and Molecules. Oxford University Press, NewYork (1989).

[30] A. D. Becke. Phys. Rev. A Gen. Phys. 38, 3098 (1988).

[31] A. D. Becke. J. Chem. Phys. 98, 5648 (1993).

[32] C. T. Lee, W. T. Yang, R. G. Parr. Phys. Rev. B. 37, 785 (1988).

[33] M. Narayanan Nair, N. Hobeika, F. Calard, J. P. Malval, S. Aloise, A. Spangenberg, L. Simon, M. Cranney, F. Vonau, D. Aubel, F. Serein-Spirau, J. P. Lere-Porte, M. A. Lacour, T. Jarrosson. Phys. Chem. Chem. Phys. 16, 12826 (2014). 